\title{
Two distinct decadal and centennial cyclicities forced marine upwelling intensity and precipitation during the late Early Miocene in central Europe
}

\author{
G. Auer ${ }^{1}$, W. E. Piller ${ }^{1}$, and M. Harzhauser ${ }^{2}$ \\ ${ }^{1}$ Institute for Earth Sciences, University of Graz, NAWI Graz, Heinrichstrasse 26, 8010 Graz, Austria \\ ${ }^{2}$ Natural History Museum Vienna, Geological-Paleontological Department, Burgring 7, 1010 Vienna, Austria \\ Correspondence to: G. Auer (gerald.auer@uni-graz.at) \\ Received: 4 March 2014 - Published in Clim. Past Discuss.: 28 March 2014 \\ Revised: 3 December 2014 - Accepted: 21 January 2015 - Published: 19 February 2015
}

\begin{abstract}
Within a $5.5 \mathrm{~m}$ thick succession of Upper Burdigalian (Karpatian) sediments in the North Alpine Foreland Basin (NAFB; Austria), dated to CNP-zone NN4, a highresolution section was logged continuously. One hundred samples were taken with a resolution of $\sim 10 \mathrm{~mm}$ (approximating $\sim 17$ years) per layer and analyzed using an integrated multi-proxy approach.

Earlier analyses of geochemistry and calcareous nannoplankton assemblages hint at small-scale, short-term variations in paleoenvironmental conditions, such as watercolumn stratification, primary productivity, organic matter flux, bottom-water oxygenation, freshwater influx, and changes in relative sea level. The results indicate a highly dynamic shallow marine setting that was subject to highfrequency environmental changes on a decadal to centennial scale.

Time-series analyses on nine different proxy data sets using REDFIT analysis and wavelet spectra were applied to resolve a possible cyclic nature of these variations. Analyses revealed that different proxies for precipitation, upwelling intensity, and overall productivity were likely controlled by different cyclicities.

A best-fit adjustment of the likely sedimentation rates within the high-resolution section resulted in periodicities fitting well with the Lower ( $\sim 65$ years) and Upper ( $\sim 113$ years) Gleissberg cycle as well as the Suess/de Vries cycle $(\sim 211$ years $)$. The section covers a time span of $\sim 1190$ years based on the correlation with solar cycles, which resulted in an estimated sedimentation rate of $575 \mathrm{~mm} \mathrm{kyr}^{-1}$.
\end{abstract}

For the first time, short-term climate variability on a decadal to centennial scale is resolved in Lower Miocene shallow marine laminated sediments in a land-based section. The results hint at a close relationship between climate variability and solar forcing during the Late Burdigalian. Moreover, accepting that these cyclicities are indeed of solar origin, this would indicate that precipitation was driven by the two Gleissberg cycles, while upwelling was driven by the Suess cycle. Furthermore, proxies for primary productivity were influenced by both cycles, although the Suess cycle exerts dominant control, reflecting a stronger influence of upwelling on primary productivity.

\section{Introduction}

Instrumental documentation of high-frequency climate behavior only reaches back several hundred years (see Le Treut et al., 2007, for an extensive discussion on the subject). Studying sediments offers a unique way to reconstruct climate variability in Earth's past, also hinting at the processes influencing such changes. Astronomical parameters are a major force of climate change on different scales. On a centennial to decadal scale, solar variation appears to be one of the key factors in determining the Earth's climate (Patterson et al., 2004, 2013; Solanki et al., 2004; Gray et al., 2010). While its causes are, for the moment, only poorly understood, solar activity clearly shows quasi-cyclic variances such as the 11year Schwabe cycle, the 22-year Hale cycle, the 50-80-year Lower Gleissberg cycle, the 90-140-year Upper Gleissberg 
cycle, the $\sim 210$-year Suess/de Vries cycle, and the 22002300-year Hallstatt cycle, as well as unnamed cycles with a 400-, 500- and 1000-year periodicity (see Kern et al., 2012, 2013, for discussion).

While cycles of solar origin are well documented in the Antarctic isotope record and ice cores (e.g., Damon and Sonett, 1991; Stuiver and Braziunas, 1993), terrestrial and marine records around the globe also show evidence of solar cycles during the Quaternary (Stuiver and Braziunas, 1993; Stuiver et al., 1995; Taricco et al., 2009; Di Rita, 2013; Galloway et al., 2013). Comparable studies from the Neogene are scarce and mostly confined to varved (Vos et al., 1997; Lindqvist and Lee, 2009; Lenz et al., 2010) sediment. Another example is laminated sediments of Miocene lakes (Gross et al., 2011; Kern et al., 2012, 2013; Harzhauser et al., 2013). These examples show clear evidence of solar cycles in the Miocene. However, studies of marine sediments on high-resolution, short-term climate variability have never been conducted in pre-Pleistocene sediments.

Generally, only specific proxies are appropriate for this type of study. Besides geochemical and geophysical proxies, only microfossils occur in suitable quantities and are small enough to allow quantitative high-resolution studies on a sub-Milankovitch scale. Based on their small size, abundance, and global distribution, calcareous nannofossils are thus uniquely suited for such studies (e.g., Ziveri et al., 2004).

While calcareous nannofossils are widely used in stratigraphy from the Mesozoic to recent, they are less often used for ecological studies, since their complex ecological preferences, while well documented, are still poorly understood (e.g., Ziveri et al., 2004). However, careful literature studies in combination with statistical analyses open up their use as a reliable proxy for the description of shifts in paleoenvironmental conditions (e.g., Couapel et al., 2007; Auer et al., 2014). Nevertheless, high-resolution studies using calcareous nannoplankton as a paleoecological proxy in the Pleistocene and Holocene have shown its potential as a proxy for decadal to centennial climate variability (Negri and Giunta, 2001; Álvarez et al., 2005; Mertens et al., 2009; Incarbona et al., 2010). It further has been proven that calcareous nannofossils are strongly influenced by cyclic variations in the Earth's climate, both on a larger Milankovich scale (Amore et al., 2012; Girone et al., 2013) and smaller scale linked to solar variation (Incarbona et al., 2010). Moreover, a tight relation to solar activity has to be expected for surface-dwelling photosynthetic organisms.

Additionally, nearly all these studies have been carried out on core samples, while calcareous nannofossils from Miocene surface outcrops have never been studied before at this resolution with a focus on the influence of solar variation on short-term climate variability. One previous study on finely laminated marine sediments of late Burdigalian age from the Central Paratethys has already documented ecological variability at such a high resolution during the late
Early Miocene. A section was studied in terms of distribution of calcareous nannofossil assemblages in combination with geochemical proxies. Based on this multi-proxy approach, a clear link was shown between abundance distributions within the coccolith assemblages and changes in local environmental conditions, such as relative sea level, freshwater influx, nutrient availability, and upwelling intensity, despite contamination of certain taxa by reworked specimens (Auer et al., 2014).

This data set has now been used to detect a possible cyclic nature in these changes and to correlate them with known decadal to centennial cycles of solar origin. Our results demonstrate that solar forcing had a strong influence on the local paleoclimate and acted as a major pacemaker for the observed cyclic variations in the paleoecological conditions within the area.

\section{Geological setting}

The investigated outcrop is situated in a brickyard near Laa an der Thaya, roughly $50 \mathrm{~km}$ north of Vienna, Austria $\left(48^{\circ} 43^{\prime} 0.84^{\prime \prime} \mathrm{N}, 16^{\circ} 24^{\prime} 45.18^{\prime \prime} \mathrm{E}\right.$; Fig. 1), where sediments of the Laa Formation are exposed. This Upper Burdigalian lithostratigraphic unit was deposited within the North Alpine Foreland Basin (NAFB), which was a part of the Central Paratethys during the Oligocene-Miocene (Harzhauser and Piller, 2007; Piller et al., 2007).

The Laa Formation corresponds to the lower to middle Karpatian (17.2-16.5 Ma; Dellmour and Harzhauser, 2012) of the regional chronostratigraphic scheme of the Central Paratethys. Grunert et al. (2012, 2010b) suggest a total range of 17.2 to 15.9 Ma for the Karpatian (Fig. 2). Seismic logs indicate a maximum thickness of up to $1000 \mathrm{~m}$ for the Laa Formation, which displays a general coarsening-upward trend (Roetzel and Schnabel, 2002; Adamek et al., 2003; Dellmour and Harzhauser, 2012).

The Laa Formation is composed of marine, calcareous, laminated, greenish to brownish grey, micaceous silty clays with thin, fine sand intercalations that unconformably overly Ottnangian sediments (Nehyba and Petrová, 2000; Roetzel and Schnabel, 2002; Adamek et al., 2003).

Paleoenvironmental reconstructions suggest an inner to outer shelf environment of 100 to $200 \mathrm{~m}$ water depth, with dysoxic bottom water conditions, based on benthic foraminiferal assemblages (Spezzaferri and Ćorić, 2001). Roetzel and Schnabel (2002) interpreted frequently occurring sandy intercalations as episodic storm events. Assemblages of calcareous nannoplankton point towards cool to temperate, nutrient-rich surface water conditions and local upwelling (Spezzaferri and Ćorić, 2001). Similar upwelling conditions have also been reported from other locations within the NAFB during the Early Miocene (Spezzaferri et al., 2002; Roetzel et al., 2007; Grunert et al., 2010c, 2012). 


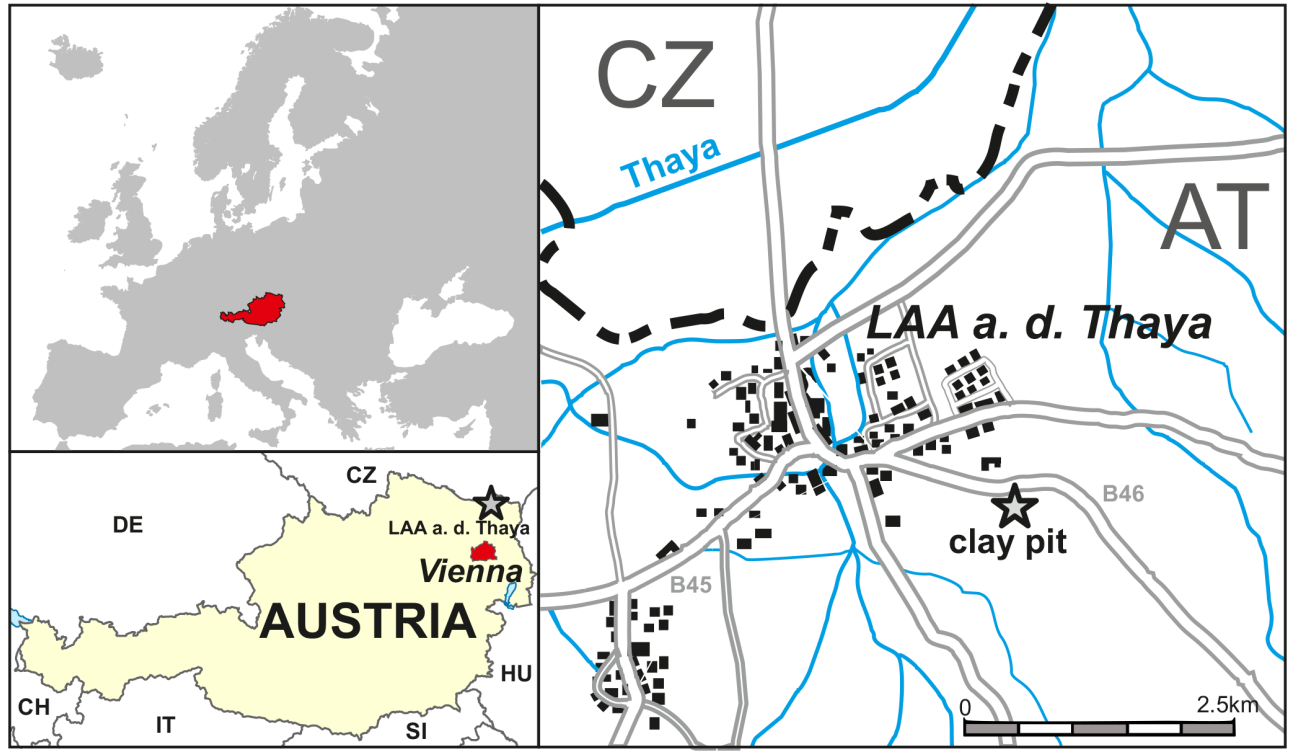

Figure 1. Map showing the position of the studied outcrop near Laa an der Thaya in Lower Austria (after Auer et al., 2014).

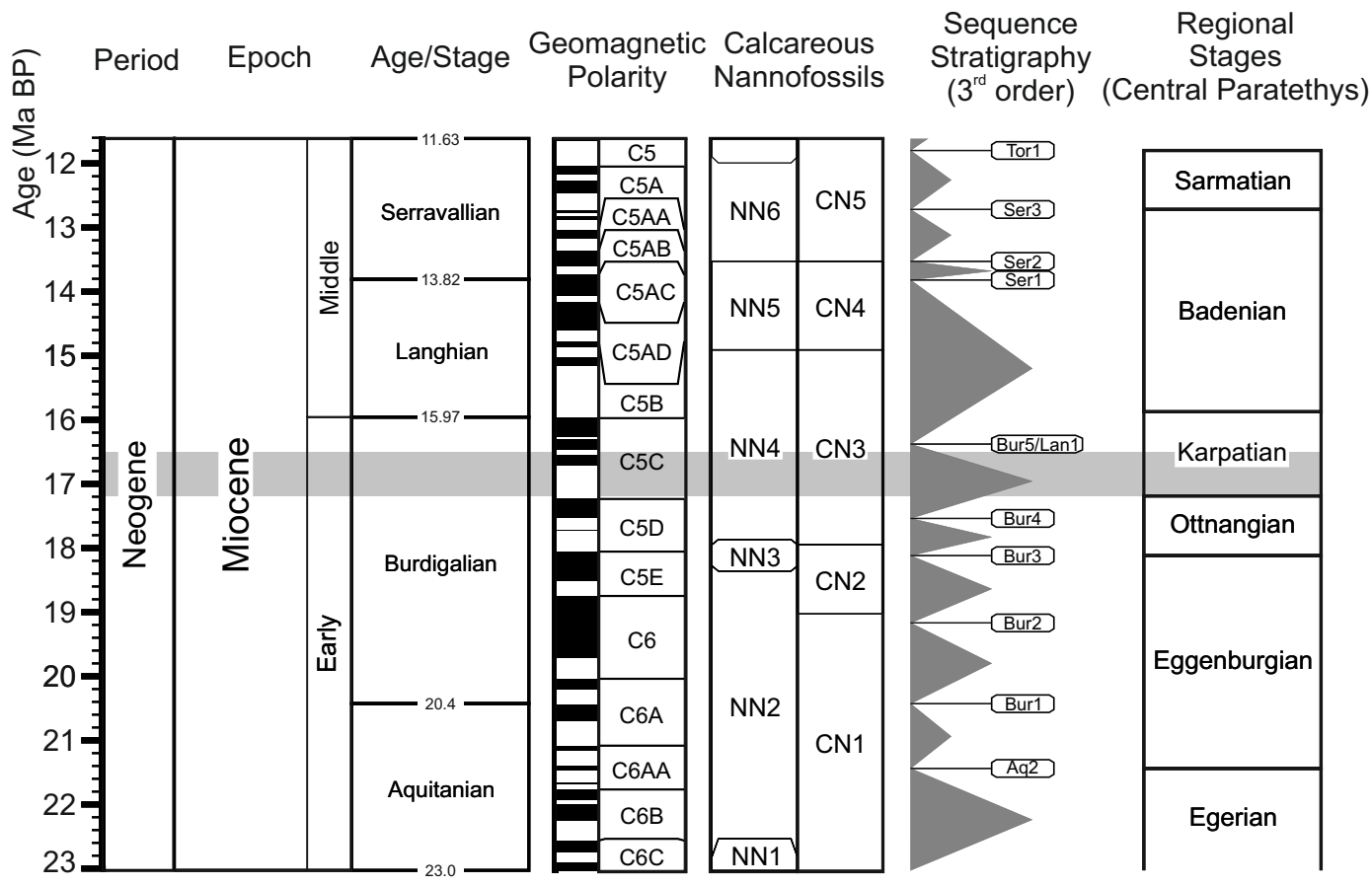

Figure 2. Stratigraphic table of the Early to Middle Miocene, showing global geochronology after Gradstein et al. (2012) and references therein. Regional stages of the Central Paratethys after Piller et al. (2007), with updated ages for the Ottnangian and Karpatian after Grunert et al. (2010b) and Dellmour and Harzhauser (2012). The grey bar indicates the stratigraphic position of the Laa Formation (after Auer et al., 2014).

Nannofossil assemblages place the Laa Formation entirely into Neogene Nannoplankton Zone NN4 of Martini (1971) (Spezzaferri and Ćorić, 2001; Spezzaferri et al., 2002; Adamek et al., 2003; Svabenicka et al., 2003), or alternatively into Mediterranean Neogene Nannoplankton zone MNN4a (Fornaciari and Rio, 1996; Fornaciari et al., 1996) and also Calcareous Nannofossil Miocene Zone CNM6 of Backman et al. (2012) (Auer et al., 2014). The assemblages are generally of low to moderate diversity with high amounts (up to $45 \%$ ) of reworked (Paleogene and Cretaceous) specimens (Auer et al., 2014). 
The studied outcrop was biostratigraphically dated using calcareous nannofossils, confirming the biostratigraphic position within MNN4a and CNM6 by the occurrence of Helicosphaera ampliaperta and rare occurrences of Sphenolithus heteromorphus,respectively. Its position within the lithostratigraphic framework of the Laa Formation cannot be determined precisely, due to a lack of detailed reference sections and cores spanning the whole formation. Nevertheless, the general placement of the outcrop is usually assumed to be in the upper part of the Laa Formation, which corresponds to the uppermost lower Karpatian (Fig. 2; Auer et al., 2014).

\section{Materials and methods}

\subsection{Sampling and field methods}

In the clay pit a $5.5 \mathrm{~m}$ thick succession of finely laminated blue-grey to green-grey clays with intercalated silt and fine sand layers is exposed. The laminated clays show variable thicknesses on a sub-millimeter to centimeter scale. The sand layers, reaching a thickness of up to $5 \mathrm{~cm}$, decrease in frequency towards the top of the succession, and show wellpreserved current ripples. The exposed sediments are mostly free of bioturbation as well as macrofossils.

Besides lithological logging, natural gamma radiation and magnetic susceptibility were measured using a portable scintillation counter (Heger-Breitband-Gammasonde) and a portable magnetic susceptibility meter (Exploranium KT-9), respectively.

Within this succession, a high-resolution sub-section with a total thickness of $940.5 \mathrm{~mm}$ was logged, composed of finely laminated clays with some intercalations of fine sand and silt. The sub-section starts at $3.06 \mathrm{~m}$ above the base of the section and contains 100 layers with a thickness of $\sim 10 \mathrm{~mm}$ that were continuously sampled using a top-down approach (Auer et al., 2014).

In the lower half of the section the clay is clearly laminated. Lamination becomes less pronounced towards the top, while sandy/silty intercalations increase in frequency. This general coarsening-upward trend is also reflected in the geophysical measurements. Furthermore, the lower boundaries of the layers become less clearly defined and increasingly wavy. Bioturbation only occurs in two successive layers close to the base of the section (Fig. 3).

\subsection{Sample preparation and treatment}

For geochemical analysis, approximately $0.1-0.15 \mathrm{~g}$ of powdered sediment for each of 100 samples was analyzed in a LECO CS230 analyzer in order to determine the weight percent of total carbon (TC), total organic carbon (TOC), and sulfur. The content of total inorganic carbon (TIC) was then calculated based on TC and TOC content (TIC $=$ TC-TOC). Using the stoichiometric formula $(8.34 \times$ TIC $)$, the calcium carbonate content was also calculated (Stax and Stein, 1995;
Grunert et al., 2010a). The ratio of organic carbon to sulfur was calculated after Berner and Raiswell (1984).

For analyses of the calcareous nannofossil assemblages, smear slides of the samples were prepared after the standard preparation methods outlined in Bown and Young (1998). Samples were not treated beforehand in order to preserve the original assemblage and ultrasonicated for $5 \mathrm{~s}$ in order to facilitate a better disarticulation of the sediment before transferring the suspension onto a cover slip. The slides were mounted using Eukitt ${ }^{\circledR}$ before being studied under a standard light microscope with a magnification of $1000 \times$ under parallel and crossed nicols. For quantitative analyses of the assemblages in terms of abundance and distribution, approximately 300 specimens were counted within each sample and identified to species level.

\subsection{Taxonomic remarks}

Calcareous nannoplankton assemblages were identified using the Nannotax website (Young et al., 2013) in combination with the taxonomy of Perch-Nielsen (1985b, a), Young (1998), Varol (1998), and Brunette (1998), supplemented by the Handbook of Calcareous Nannoplankton 1-5 (Aubry, 1984; 1988, 1989, 1990, 1999). The revised taxonomy for the Paratethys published by Galović and Young (2012) was also taken into consideration.

Recorded taxa were first identified to species level and then grouped according to their stratigraphic range in order to quantify the amount of allochthonous taxa present within the assemblages, and also to create a stratigraphic framework for the section.

For the genus Reticulofenestra the standard size definition of Young (1998) was used: Reticulofenestra minuta $<3 \mu \mathrm{m}$, $R$. haqii 3-5 $\mu \mathrm{m}$, and $R$. pseudoumbilicus $>5 \mu \mathrm{m}$. The distinction of medium-sized reticulofenestrids based on their central area ( $R$. haqii, open; $R$. antarctica, closed) (e.g., Wade and Bown, 2006) was not used in this study.

A total of 124 calcareous nannofossil taxa were identified, of which 24 occur within nannoplankton zone NN4 and represent an average of $67.86 \%(\sigma=5.33)$ of the total assemblage. The autochthonous assemblage includes five taxa with an average abundance of $>1 \%$ (see Table 1; Auer et al., 2014). Many of these taxa have a wide stratigraphic range, and partial reworking cannot be excluded for certain taxa (e.g., Coccolithus pelagicus, Cyclicargolithus floridanus, Sphenolithus moriformis, and Reticulofenestra min$u t a)$. These taxa were considered as entirely autochthonous, since reworked specimens could not be distinguished from autochthonous ones. Nevertheless, statistical analysis and paleoecological reconstructions support that a primary ecological signal is preserved within the assemblage, despite likely partial reworking (Auer et al., 2014).

The remaining 100 taxa are all clearly allochthonous of both Paleogene and Cretaceous age. Forty-one taxa can be attributed to mainly Paleocene and Eocene ages. The Cre- 


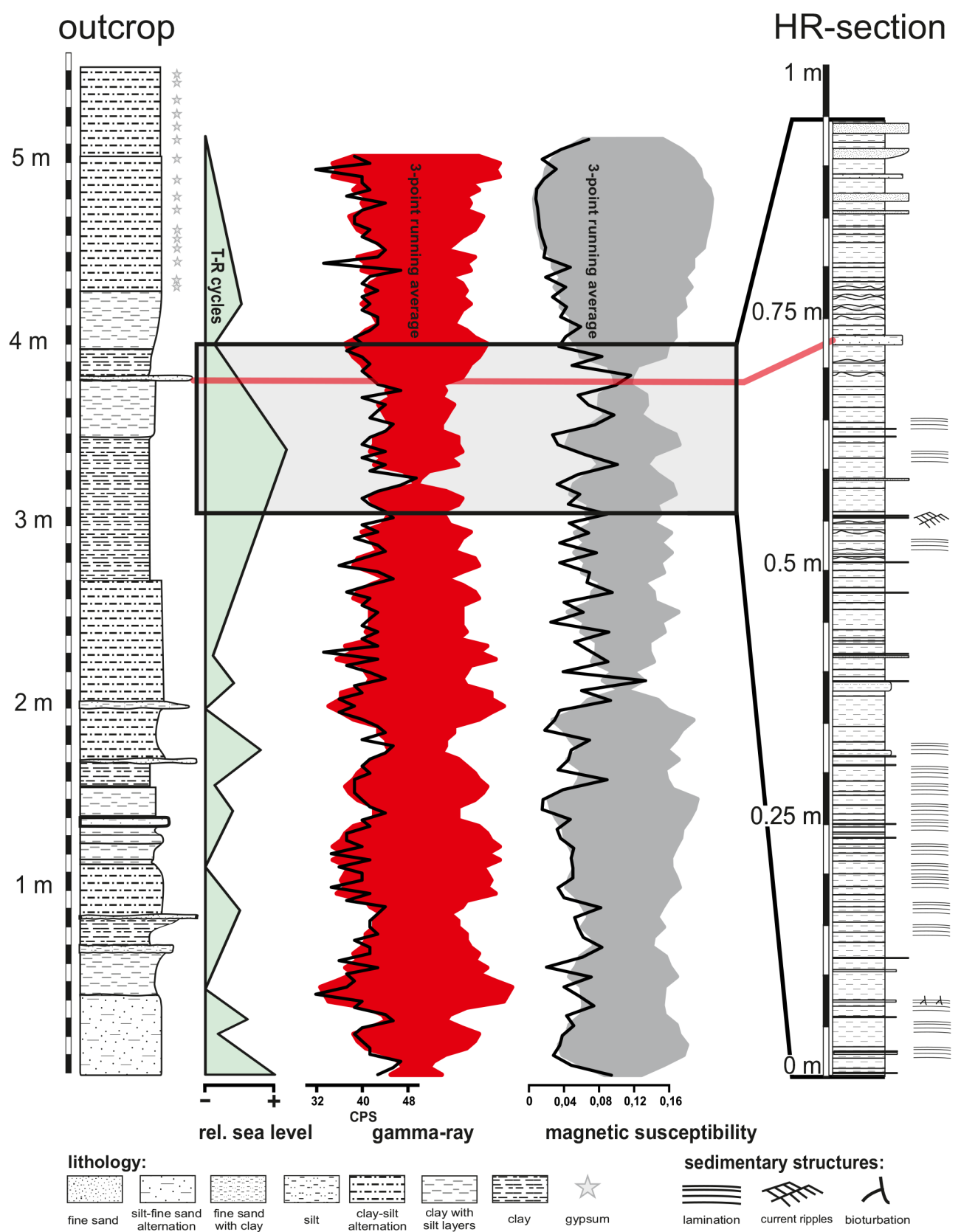

Figure 3. Lithologs of the $5.5 \mathrm{~m}$ sedimentary succession and the high-resolution (HR) section. The position of the high-resolution section within the succession is marked by the grey rectangle; the red line denotes a distinct marker layer that was used as a tie point. Relative sea level was reconstructed using gamma-ray logs. Gamma-ray logs (in CPS) and magnetic susceptibility of the outcrop are shown as black lines. A three-point running mean for both logs was plotted as a mirrored column (after Auer et al., 2014).

taceous assemblage is represented by 59 taxa of mainly Campanian to Maastrichtian age. All 100 taxa of the allochthonous assemblages were grouped together and used as a proxy for terrigenous input in subsequent analyses (Auer et al., 2014).

\subsection{Spectral analysis and best-fit tuning}

Since any observed abundance of calcareous nannoplankton is not normally distributed, the counts were transformed using the arcsine transformation, as outlined in Sokal and Rohlf (1995). The reason for using a transformation was to create a more normally distributed data set that is better suited for the subsequent analyses. 

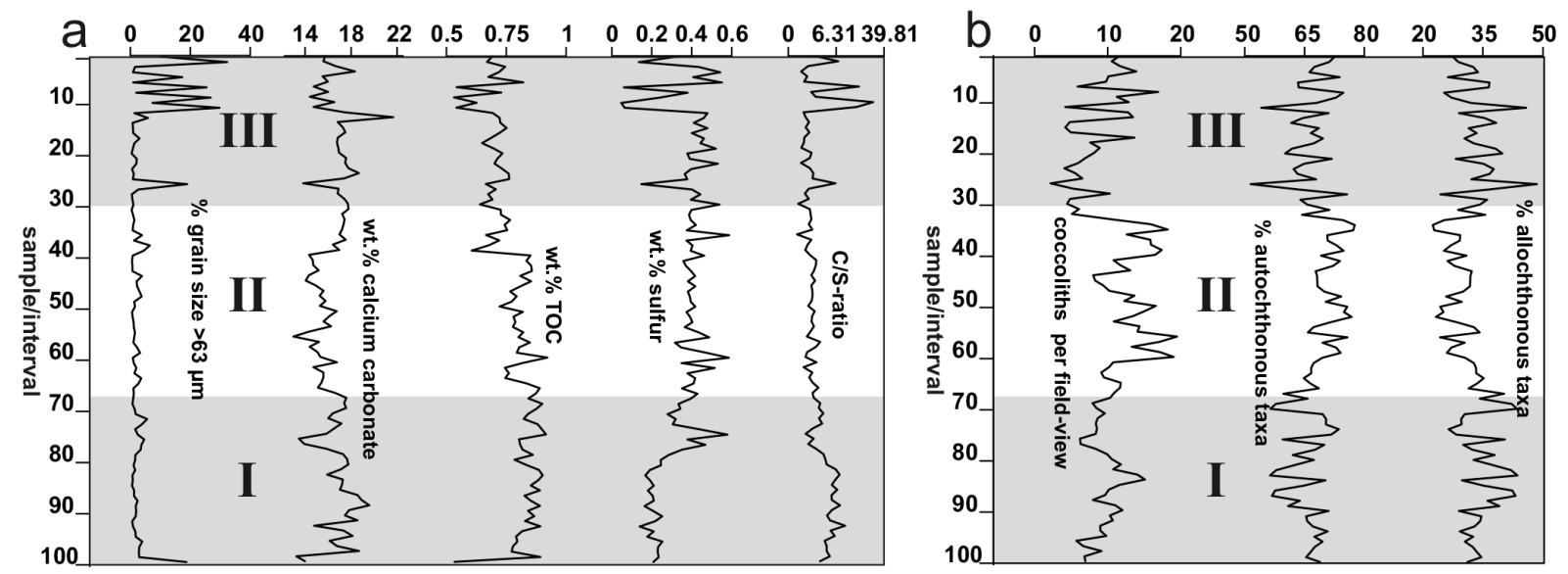

Figure 4. Sedimentological ( $\%$ of grains $>63 \mu \mathrm{m}$ ) and geochemical parameters (calcium carbonate, organic carbon, sulfur, and C/S ratio) of the high-resolution section (a). Coccolith abundances are shown as coccoliths encountered per field view of the light microscope and the abundance of autochthonous and allochthonous specimens in percent (b). Three basic depositional intervals (I-III) were defined based on a simple visual evaluation of the gathered data sets.

Table 1. Overview of the nine studied proxies. Table shows highest and lowest values, average content (arithmetic mean), and the standard deviation.

\begin{tabular}{lrrrr}
\hline & Max & Min & Average & $\sigma(\mathrm{pp})$ \\
\hline Calcium carbonate (wt \%) & 22.7 & 13.02 & 16.44 & 1.48 \\
Sulfur (wt \%) & 0.57 & 0.03 & 0.33 & 0.05 \\
TOC (wt \%) & 0.92 & 0.53 & 0.78 & 0.09 \\
Coccolithus pelagicus (\%) & 46.62 & 22.7 & 34.52 & 4.89 \\
Cyclicargolithus floridanus (\%) & 17.76 & 2.96 & 8.57 & 3.22 \\
Reticulofenestra haqii (\%) & 13.04 & 1.32 & 5.76 & 2.5 \\
Reticulofenestra minuta (\%) & 26.67 & 3.3 & 12.48 & 4.93 \\
Reticulofenestra pseudoumbilicus $(\%)$ & 5.45 & 0 & 2.18 & 1.2 \\
Autochthonous taxa < $\%(\%)$ & 7.52 & 0.32 & 4.06 & 1.61 \\
Allochthonous taxa (\%) & 48.52 & 22.44 & 32.44 & 5.37 \\
\hline
\end{tabular}

Spectral analyses of geochemical and paleobiological data sets were performed using the REDFIT tool of the PAST statistics package (v. 2.17; Hammer et al., 2001). The REDFIT analysis was selected based on the fact that REDFIT was specifically designed to handle unevenly spaced noisy data (Schulz and Mudelsee, 2002). This made the method ideal for the analysis of data sets based on layers of varying thickness.

Prior to analysis, the samples were evaluated based on their sedimentological, geochemical, and taphonomic characteristics and separated into three depositional intervals (Figs. 4, 5). Based on this simple evaluation, the topmost 30 samples of the section were excluded due to intercalations of coarser sediment indicating changes in the sedimentation rate (Figs. 4, 5). Such strong disturbances in sediment accumulation are usually detrimental to the detection of clear signals of periodic cycles in the section (Weedon, 2003). For the remaining 70 samples, with an overall thickness of $684 \mathrm{~mm}$, an on average stable mass budget of sediment deposition was assumed that was not directly affected by episodic storm events or heightened riverine input caused by episodic floods. While sedimentation rates naturally were not fully constant, minor quasi-random changes in sedimentation rate do not adversely affect the methods used (see Weedon, 2003). Within REDFIT, such variations in sedimentation rate are simply expressed as broadened peaks in the power spectrum, indicating that cycles are subject to slight variations in frequency over time. The peaks are, however, still centered on the significant frequency (Weedon, 2003).

In order to consider the thickness of the sampled layers, two data points were used for each sample. One data point was set at the bottom and one at the top of the layer. This was done to express each sample as a continuous layer instead of one single data point. In total, nine data sets (three geochemical and six based on coccolith abundance data) were analyzed using REDFIT. The five autochthonous coccolith taxa used were selected due to their high abundance and specific eco- 

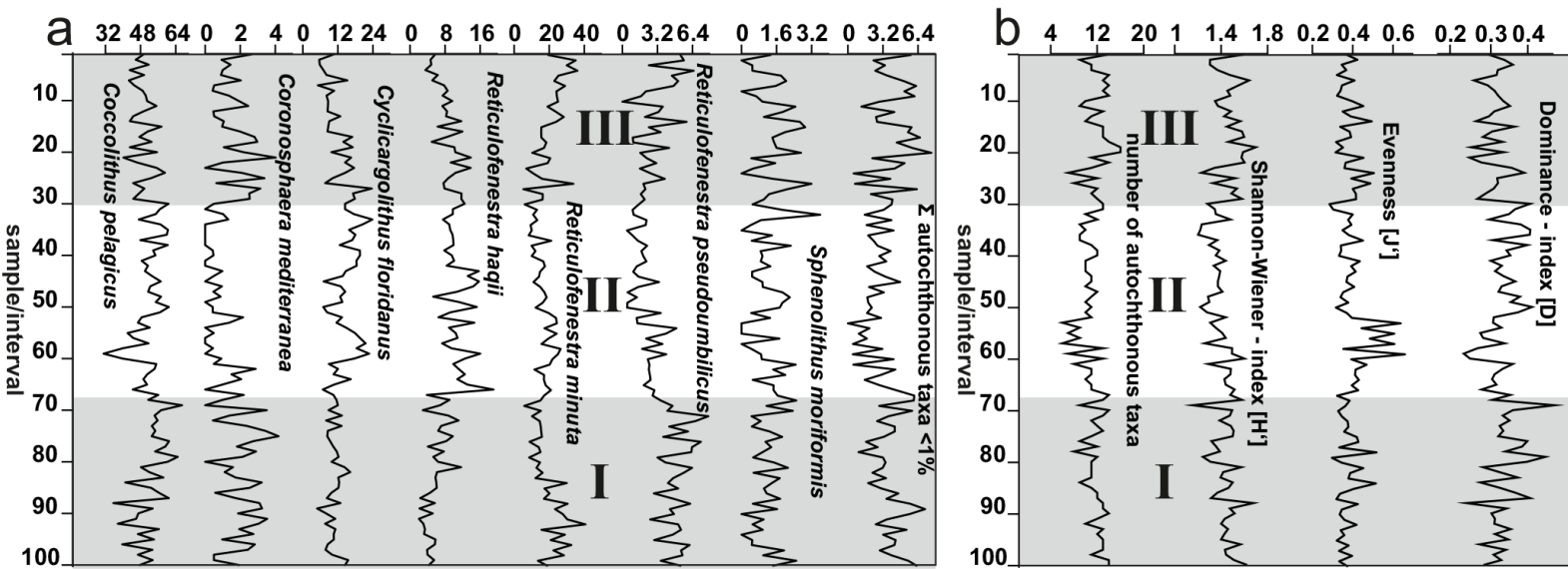

Figure 5. Relative abundances of autochthonous coccolith taxa $>1 \%$ as well as the abundance of autochthonous taxa $<1 \%$, normalized to $100 \%$, within each sample of the high-resolution section (a). Diversity indices show the amount of autochthonous taxa, the Shannon-Wiener index, species evenness, and the dominance index of the studied samples (b). The three intervals (I-III) show the depositional episodes defined by visual evaluation of the gathered data sets.

logical preferences. The amount of allochthonous taxa was used as a proxy for terrigenous input.

For the calculation of the REDFIT periodograms, different windows as well as segmentations and oversampling rates were applied to all data sets (see Table 2). This was done in order to achieve clear peaks in the periodograms for each separate data set (Hammer, 2010).

After performing the REDFIT analysis on the data sets of all relevant samples, a Monte Carlo simulation was performed on the resulting power spectra in order to test the time series under white-noise conditions before examination of significant peaks (Hammer et al., 2001; Hammer, 2010). Peaks were considered significant with a confidence interval (CI) of $>95 \%$ in the REDFIT analysis. In some instances, periodicities below a CI of $95 \%$ were also included in the interpretation since they were located at the same frequencies as significant $(>95 \%)$ periodicities in other data sets (Table 3).

In order to eliminate any artificial peaks created by the REDFIT analysis, the Nyquist frequency was used. The Nyquist frequency is the highest possible frequency in a sampled set that can be expressed by a simple sine or cosine wave, and is generally assumed to be a frequency of twice the average sampling distance (Weedon, 2003). Consequently, the Nyquist frequency is calculated using the reciprocal value of the total thickness of the section $(684 \mathrm{~mm})$ divided by twice the amount of samples used (70). For the studied highresolution section the Nyquist frequency can thus be calculated as $1 /(684 /(70 \times 2))$. This calculation yields a value for the highest possible frequency that is not an artifact created by the REDFIT method as $f=0.051$. This translates into a periodicity of about $19.6 \mathrm{~mm}$. Below this threshold, periodicities are assumed to be artifacts and were excluded from subsequent analysis. Weedon (2003) suggests a minimal spacing of four samples per sinusoid, which would effectively double the minimal periodicity of cycles to roughly $39 \mathrm{~mm}$. For our analysis we also considered periodicities of 25 to $30 \mathrm{~mm}$ as viable, because of the fact that the Nyquist frequency is based on average sample spacing, but our samples cover variable thicknesses and are often thinner than the calculated average thickness of $9.77 \mathrm{~mm}$. Additionally, any frequencies above a periodicity larger than half the total thickness of the section $(342 \mathrm{~mm})$ were also considered to be of insufficient significance to safely assume the presence of those periodicities. Therefore all frequency components below $f=0.003$ were also excluded.

An automatic linear interpolation was used to create data sets with 1000 new, evenly spaced data points without compromising the shape of the original curve. These data sets were used for methods (filtering and wavelet analyses) that require evenly spaced data sets.

Periodicities, as detected by the REDFIT periodograms, were filtered using Gaussian band-pass filter in the application Analyseries (Paillard et al., 1996). The method selects only the desired frequency components of a given data set, and displays their amplitude, while removing all other frequencies. To encompass the whole range of the selected frequencies, a bandwidth with the size of $25 \%$ of the frequency was applied to all Gaussian band-pass filters. Band-pass filtering is now standard practice for modern cyclostratigraphy, since it allows for a better examination of the varying degrees of influence the detected frequencies have over a time interval (Weedon, 2003).

To further evaluate any detected and filtered periodicities wavelet analyses were also performed on all investigated data sets using the corresponding tool from the PAST statistics package (Hammer, 2010; Hammer et al., 2001). wavelet spectra allow for simultaneous graphic examination of all 

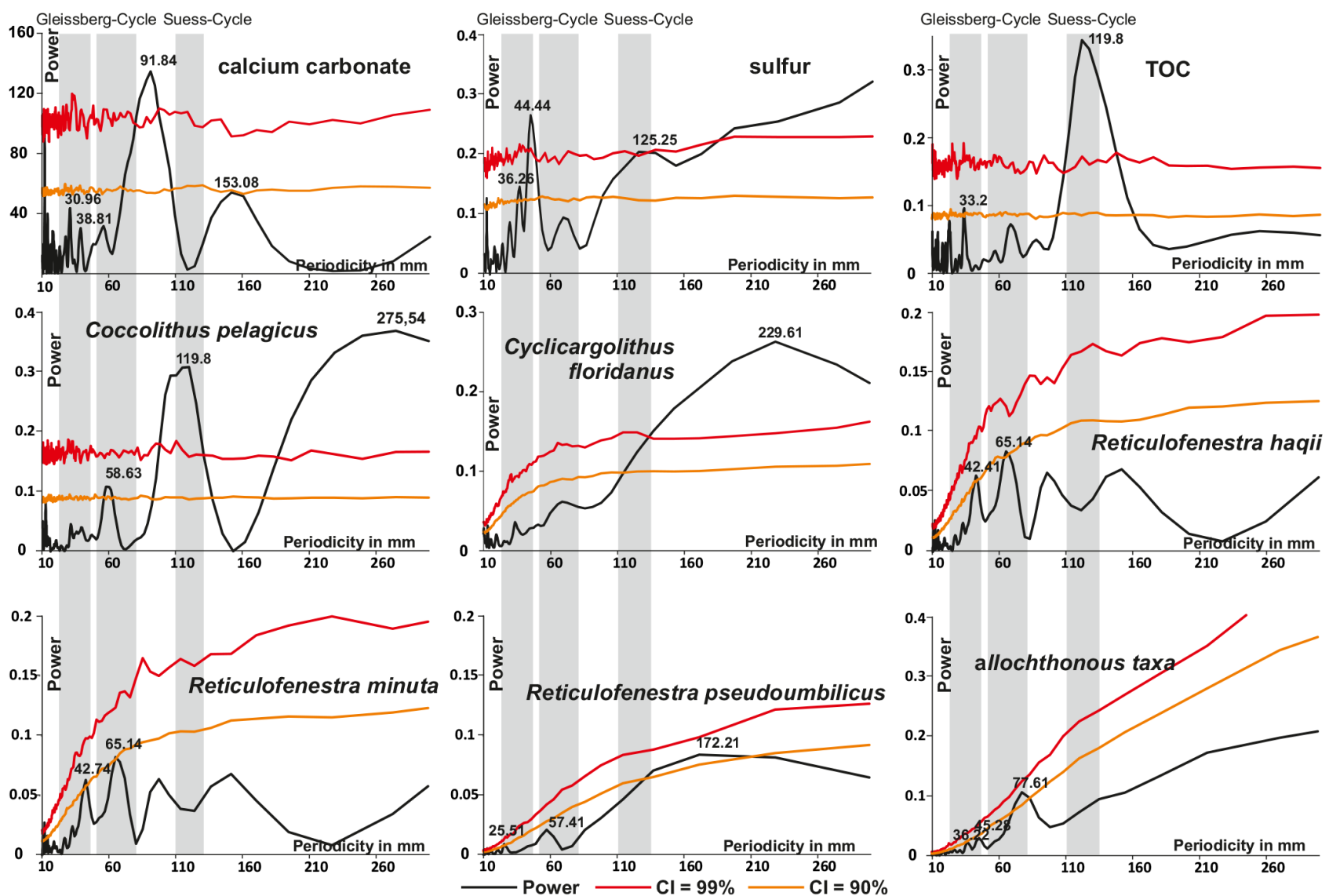

Figure 6. Periodograms of the nine investigated geochemical and paleoecological proxies showing their respective periodicities in millimeters calculated using REDFIT. Black lines indicate the power of the frequency components. Red and orange lines respectively show the 99 and $90 \%$ confidence intervals (CI) of the REDFIT analyses. Grey bars represent the reported periodicities of the Lower and Upper Gleissberg cycle, and the Suess/de Vries cycle.

Table 2. Overview of the setting used in REDFIT for the nine studied proxies.

\begin{tabular}{llcc}
\hline & Window & Segments & Oversample \\
\hline Calcium carbonate & Blackman-Harris & 1 & 4 \\
Sulfur & Blackman-Harris & 2 & 4 \\
TOC & Welch & 3 & 4 \\
Coccolithus pelagicus & Blackman-Harris & 1 & 4 \\
Cyclicargolithus floridanus & Blackman-Harris & 3 & 4 \\
Reticulofenestra haqii & Welch & 2 & 4 \\
Reticulofenestra minuta & Welch & 2 & 3 \\
Reticulofenestra pseudoumbilicus & Welch & 3 & 2 \\
Allochthonous taxa & Rectangle & 4 & 4 \\
\hline
\end{tabular}

found frequencies in combination with their amplitude at each data point of a given data set. This method was developed to accurately trace possible frequency and amplitude modulations of detected periodicities throughout a time series (Torrence and Compo, 1998; Hammer et al., 2001; Weedon, 2003; Hammer, 2010). Assuming stable frequencies over time, this further allows for estimations of occurring changes in sedimentation rate.
Following the methods used by Kern et al. (2012), the correlation with known cycles in the centennial to millennial band was achieved by a best-fit adjustment of likely sedimentation rates. The rates were initially estimated from both the calculation of the maximum mean sedimentation rate of the Laa Formation and comparison of sedimentation rates in similar recent sedimentary environments. Based on these initial constraints on sedimentation rates, average rates were ad- 
Table 3. Summary of results of the REDFIT analysis for the nine analyzed proxies. Table shows the detected frequencies, their confidence intervals (Monte Carlo corrected), and the resulting periodicity in millimeters. Periodicities in millimeters were then transformed into periodicities in years using a sedimentation rate of $575 \mathrm{~mm} \mathrm{kyr}^{-1}$ (best-fit adjustment to known solar cycles).

\begin{tabular}{|c|c|c|c|c|}
\hline & $\begin{array}{r}\text { Frequencies } \\
\qquad(1 / \mathrm{mm})\end{array}$ & $\begin{array}{r}\text { Confidence } \\
(\% \mathrm{MoCa} \text { AR } 1)\end{array}$ & $\begin{array}{r}\text { Periodicity } \\
(\mathrm{mm})\end{array}$ & $\begin{array}{r}\text { Periodicity } \\
\left(575 \mathrm{~mm} \mathrm{kyr}^{-1}\right)\end{array}$ \\
\hline \multirow[t]{4}{*}{ Calcium carbonate } & 0.0065326 & $>90 \%$ & 153.08 & 266.23 \\
\hline & 0.0108826 & $>99 \%$ & 91.84 & 159.72 \\
\hline & 0.025768 & $>80 \%$ & 38.81 & 67.50 \\
\hline & 0.0323 & $<90 \%$ & 30.96 & 53.84 \\
\hline \multirow[t]{3}{*}{ Sulfur } & 0.0079843 & $>99 \%$ & 125.25 & 217.83 \\
\hline & 0.022501 & $>99 \%$ & 44.44 & 77.29 \\
\hline & 0.027582 & $>95 \%$ & 36.26 & 63.06 \\
\hline \multirow[t]{2}{*}{ TOC } & 0.0083473 & $>99 \%$ & 119.8 & 208.35 \\
\hline & 0.030123 & $>90 \%$ & 33.2 & 57.74 \\
\hline \multirow[t]{3}{*}{ Coccolithus pelagicus } & 0.0036292 & $>99 \%$ & 275.54 & 479.20 \\
\hline & 0.0083472 & $>99 \%$ & 119.8 & 208.35 \\
\hline & 0.017057 & $>90 \%$ & 58.63 & 101.97 \\
\hline Cyclicargolithus floridanus & 0.0043551 & $>99 \%$ & 229.61 & 399.32 \\
\hline \multirow[t]{2}{*}{ Reticulofenestra haqii } & 0.015351 & $>90 \%$ & 65.14 & 113.29 \\
\hline & 0.023575 & $>90 \%$ & 42.41 & 73.76 \\
\hline \multirow[t]{2}{*}{ Reticulofenestra minuta } & 0.015351 & $>90 \%$ & 65.14 & 113.29 \\
\hline & 0.023392 & $>90 \%$ & 42.74 & 74.33 \\
\hline \multirow[t]{3}{*}{ Reticulofenestra pseudoumbilicus } & 0.0058068 & $>95 \%$ & 172.21 & 299.50 \\
\hline & 0.039196 & $>90 \%$ & 25.51 & 44.37 \\
\hline & 0.01742 & $<80 \%$ & 57.41 & 99.84 \\
\hline \multirow[t]{3}{*}{ Allochthonous taxa } & 0.0138 & $>90 \%$ & 77.61 & 134.97 \\
\hline & 0.027608 & $>80 \%$ & 45.28 & 78.75 \\
\hline & 0.022086 & $>80 \%$ & 36.22 & 62.99 \\
\hline
\end{tabular}

justed uniformly for the whole section to tune the detected periodicities to known decadal to centennial cycles of the solar band. This approach preserves the relationship between the detected periodicities, which can then be fitted to the characteristic spectral pattern of known cycles (e.g., Weedon, 2003; Kern et al., 2012).

\section{Results}

For the detection of possible cyclicities in the high-resolution section, nine relevant data sets were selected for the REDFIT analysis (Fig. 6). These data sets include geochemical (calcium carbonate, sulfur, TOC; Table 1) and paleobiological proxies, with the five autochthonous taxa $>1 \%$, as well as all lumped allochthonous taxa (Table 1). The detected frequencies and periodicities for the nine data sets are shown in Table 3. Found periodicities, variations in the filtered amplitudes, and the correlation with the wavelet analyses are below described in detail for each respective data set:

Calcium carbonate displays significant peaks at periodicities of 91.84 and $153.08 \mathrm{~mm}$, as well as 38.81 and $30.96 \mathrm{~mm}$. The relative proximity of the latter two periodicities indicates that they may represent two different frequency components of the same periodicity, and therefore they were considered further (Fig. 7), even though they do not cross the $90 \%$ confidence level. Their inclusion is also supported by the appearance of similar cycles in related proxies. Filtering indicates that the $91.84 \mathrm{~mm}$ periodicity has an amplitude modulation 

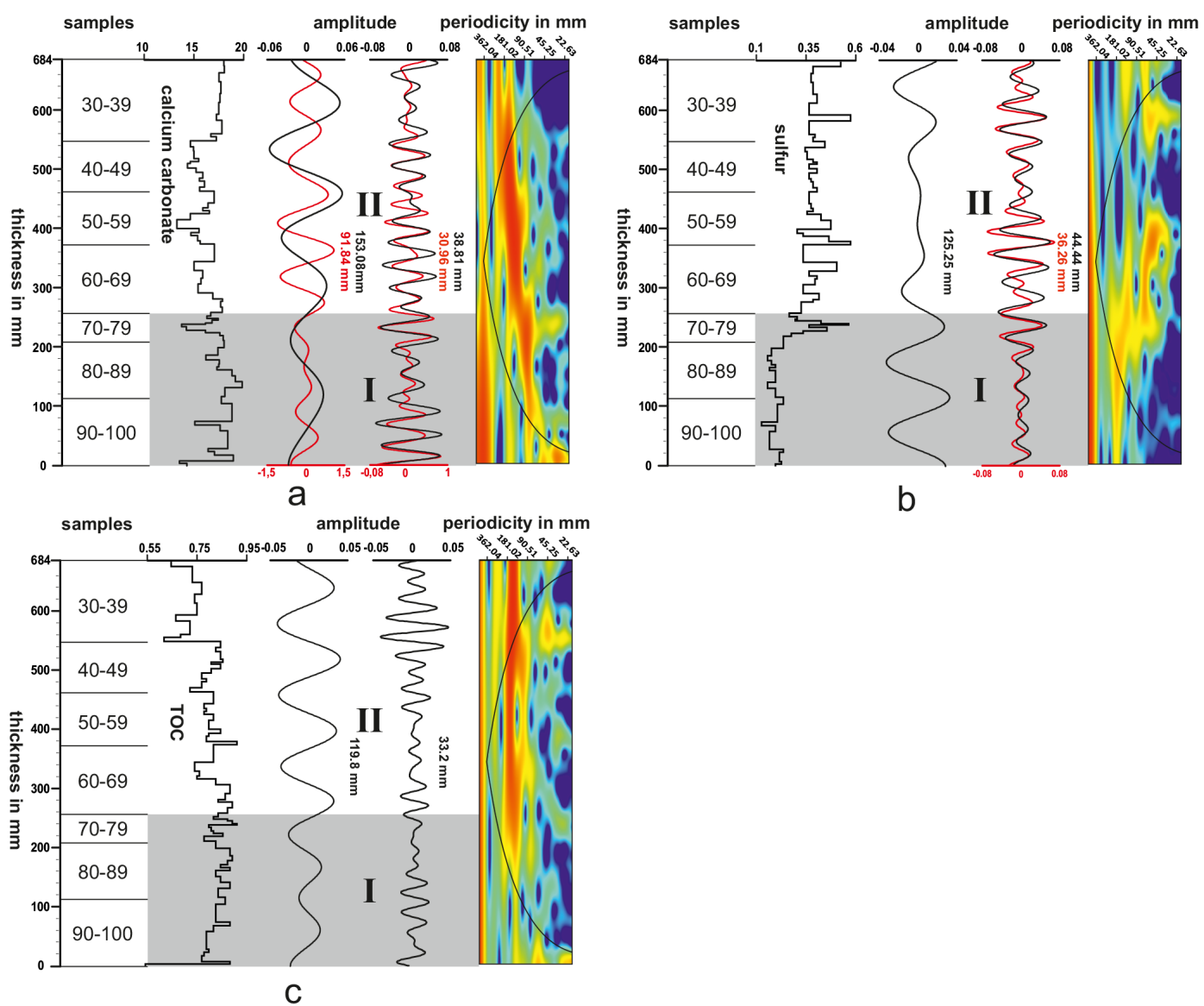

Figure 7. Geochemical data sets (calcium carbonate, sulfur, and TOC): data were transformed to reflect thicknesses of the sampled layers and filtered according to the periodicities detected by REDFIT. Gaussian filters applied to the periodicities use a bandwidth of $25 \%$ of the filtered frequency. wavelet spectra were used to evaluate the frequencies for spectral shifts; red areas of the wavelet indicate stronger amplitudes.

indicative of a very strong influence in the middle and upper part of the section (Fig. 7a). This pattern hints at a steady increase in influence over the section. The amplitude modulation for the $153.08 \mathrm{~mm}$ periodicity reveals an increase in the mid-part of the section, where it nearly doubles in intensity, staying constant until the top of the section (Fig. 7a). The two periodicities of lower significance ( 38.81 and $30.96 \mathrm{~mm}$ ) show a remarkably similar amplitude modulation over the section, further hinting at their close relationship to each other. Their influence dominates the lower part of the section, which is followed by a strong decline before increasing in amplitude synchronously with the $91.81 \mathrm{~mm}$ periodicity, followed by a gradual decline towards the top of the section (Fig. 7a). The wavelet analysis also supports the filtered periodicities detected by REDFIT. Other frequencies not detected by the REDFIT analysis also occur in the wavelet but were thus not considered significant (Fig. 7a).

Sulfur yields two peaks at periodicities of 125.25 and $44.44 \mathrm{~mm}$, respectively. Another less significant peak occurs at a periodicity of $36.26 \mathrm{~mm}$ (Fig. 6). Applying a Gaussian filter to the periodicities revealed that the $125.25 \mathrm{~mm}$ period- icity dominates the lower part of the section but is much less pronounced in the middle and upper part. The two higher periodicities of 44.44 and $36.26 \mathrm{~mm}$ show an inverse pattern. They also show a similar pattern in amplitude modulation over time, hinting at a close relationship between them (Fig. 7b). The wavelet analysis also supports the periodicities detected by REDFIT (Fig. 7b).

TOC reveals two peaks at periodicities of 119.8 and $33.2 \mathrm{~mm}$ (Fig. 6). Applying a Gaussian filter reveals amplitudes for the $119.8 \mathrm{~mm}$ periodicity that are lower at the bottom of the section but increase towards the top. The $33.2 \mathrm{~mm}$ periodicity exhibits generally lower amplitudes over most of the section, and only increases close to the top (Fig. 7c). Both frequencies are well represented in the wavelet analysis, although they show a slight spread. This implies that periodicities detected by REDFIT may be subject to a slight variability over time, likely caused by minor random changes in sedimentation rates (Fig. 7c).

Coccolithus pelagicus displays three significant peaks at periodicities of $275.54,119.8$, and $58.63 \mathrm{~mm}$, respectively (Fig. 6). The amplitudes for the $275.54 \mathrm{~mm}$ periodicity dis- 
play a constant decrease towards the top of the section. The $119.8 \mathrm{~mm}$ periodicity increases in amplitude towards a maximum in the upper middle part of the section before decreasing slightly towards the top. The periodicity of $58.63 \mathrm{~mm}$ shows much more variable amplitudes. Amplitude maxima for this periodicity are located at the bottom and top of the section, with lower amplitudes in the middle part. A slightly less pronounced increase in amplitude can also be detected in the upper middle part of the section (500 to $550 \mathrm{~mm}$; Fig. 8a). All frequencies detected by the REDFIT analysis are represented in the wavelet analysis and also correlate with the filtered amplitudes (Fig. 8a).

Cyclicargolithus floridanus only exhibits a single peak with a periodicity of $229.61 \mathrm{~mm}$ (Fig. 6). The filtering reveals constantly increasing amplitudes throughout the section (Fig. 8b). The wavelet analysis also shows the $229.61 \mathrm{~mm}$ periodicity with a significant intensity (Fig. 8b). Additionally, other frequencies appear in the wavelet analysis. Although not significant, they show a striking similarity to periodicities observed within the eight other proxies.

Reticulofenestra haqii has two peaks with periodicities of 65.14 and $42.41 \mathrm{~mm}$ (Fig. 6). Filtering reveals rather low amplitudes for the $65.14 \mathrm{~mm}$ periodicity, with a single strong excursion centered on sample 66 . The $42.41 \mathrm{~mm}$ periodicity increases in amplitude in the lower part of the section, remains rather constant to sample 39, but vanishes nearly completely above (Fig. 8c). The wavelet diagram shows a good correlation between the detected intensities of the periodicities (Fig. 8c).

Reticulofenestra minuta exhibits strikingly similar periodicities to $R$. haqii with peaks at 65.14 and $42.74 \mathrm{~mm}$ (Fig. 6). Filtering shows that the $65.14 \mathrm{~mm}$ periodicity shows strongly varying amplitudes with excursions at the bottom and very top of the section. Highest amplitudes are located at an excursion in the middle part centered at sample 66 . The $42.74 \mathrm{~mm}$ periodicity remains constantly low in amplitudes, with only a short increase from sample 50 up to 35 . At the top it vanishes nearly completely (Fig. 8d). The calculated wavelet diagram corresponds well to the detected frequencies and shows no frequency drift (Fig. 8d).

Reticulofenestra pseudoumbilicus reveals two peaks with periodicities of 172.21 and $25.51 \mathrm{~mm}$. Another distinct but not significant peak appears at a periodicity of $57.41 \mathrm{~mm}$ (Fig. 6). Filtering shows increasing amplitudes for the $172.21 \mathrm{~mm}$ periodicity peaking at sample 48 , and a decrease towards the top. The $25.51 \mathrm{~mm}$ periodicity displays highly fluctuating amplitudes throughout the section, with a maximum centered on sample 49 (Fig. 8e). The $57.41 \mathrm{~mm}$ periodicity shows constantly low amplitudes that nearly vanish for a short period in the middle part of the section (Fig. 8e).

The allochthonous taxa show three peaks with periodicities of 77.61, 45.28, and $36.22 \mathrm{~mm}$ (Fig. 6). Filtering the periodicities reveals that the $77.61 \mathrm{~mm}$ periodicity exhibits quite low amplitudes in the lower part of the section, before increasing at sample 80 . Following this increase the amplitude remains constant throughout the section. The two remaining periodicities show similar amplitude modulations throughout the section. They exhibit rather low amplitudes with a single excursion detected between sample 91 and 65 (Fig. 8f). The wavelet correlates well with the periodicities detected by REDFIT and shows no significant frequency drifts (Fig. 8f).

\section{Discussion}

\subsection{Assumptions regarding sedimentation rates and the presence of solar cycles}

Preliminary sedimentation rate estimates can be obtained by calculating the total mean sedimentation rate of the Laa Formation. Based on literature data, up to $1000 \mathrm{~m}$ of sediment was deposited in $\sim 700 \mathrm{kyr}$, giving a maximum time-averaged sedimentation rate of $1420 \mathrm{~mm} \mathrm{kyr}^{-1}$ for the whole formation (Roetzel and Schnabel, 2002; Dellmour and Harzhauser, 2012). The finely laminated sediments of the studied section, which contrast with often sandy and thickly bedded sediments in the rest of the formation, also indicate that the sedimentation rates within the high-resolution section should be considerably lower.

In the absence of any direct data on the average sedimentation rate of the finely laminated sediments encountered in the outcrop, existing sedimentation rate estimates from similar depositional environment in a more basin-ward position were used as a rough baseline (Hohenegger et al., 2009; Hohenegger and Wagreich, 2011). Cross-correlation with the $100 \mathrm{kyr}$ eccentricity and 41 kyr obliquity cycles suggests an average sedimentation rate of $\sim 512 \mathrm{~mm} \mathrm{kyr}^{-1}$ for the Baden-Sooss core (Hohenegger et al., 2009; Hohenegger and Wagreich, 2011). While the estimates are reliable for a Milankovitch scale and thus provide reasonable long-term sedimentation rates, they do not account for any sub-Milankovitch variation in sediment accumulation, which are likely to occur in such a setting. Consequently, the calculated sedimentation rates should only be considered an indication for the general range of sedimentation rates in shallow neritic settings of the Central Paratethys and can be used as an estimate of the sedimentation rates of laminated sediments encountered in the present study.

While this is arguably only provides a tentative indication of the actual sedimentation rate for the Laa section, it nevertheless supports the assumption that the cycles found within the studied section should be placed within the temporal range of the solar band, providing a tuning target for the encountered cycles (Solanki et al., 2004; Kern et al., 2012, 2013). This approach, however, depends on how the frequencies of known cycles are related to each other. A best-fit adjustment is only possible if the spectral peaks within the data sets are spaced at similar intervals to known solar cycles. This is similar to the principle that Milankovitch cycles always show a relationship of approximately $1: 4: 10: 20$ 

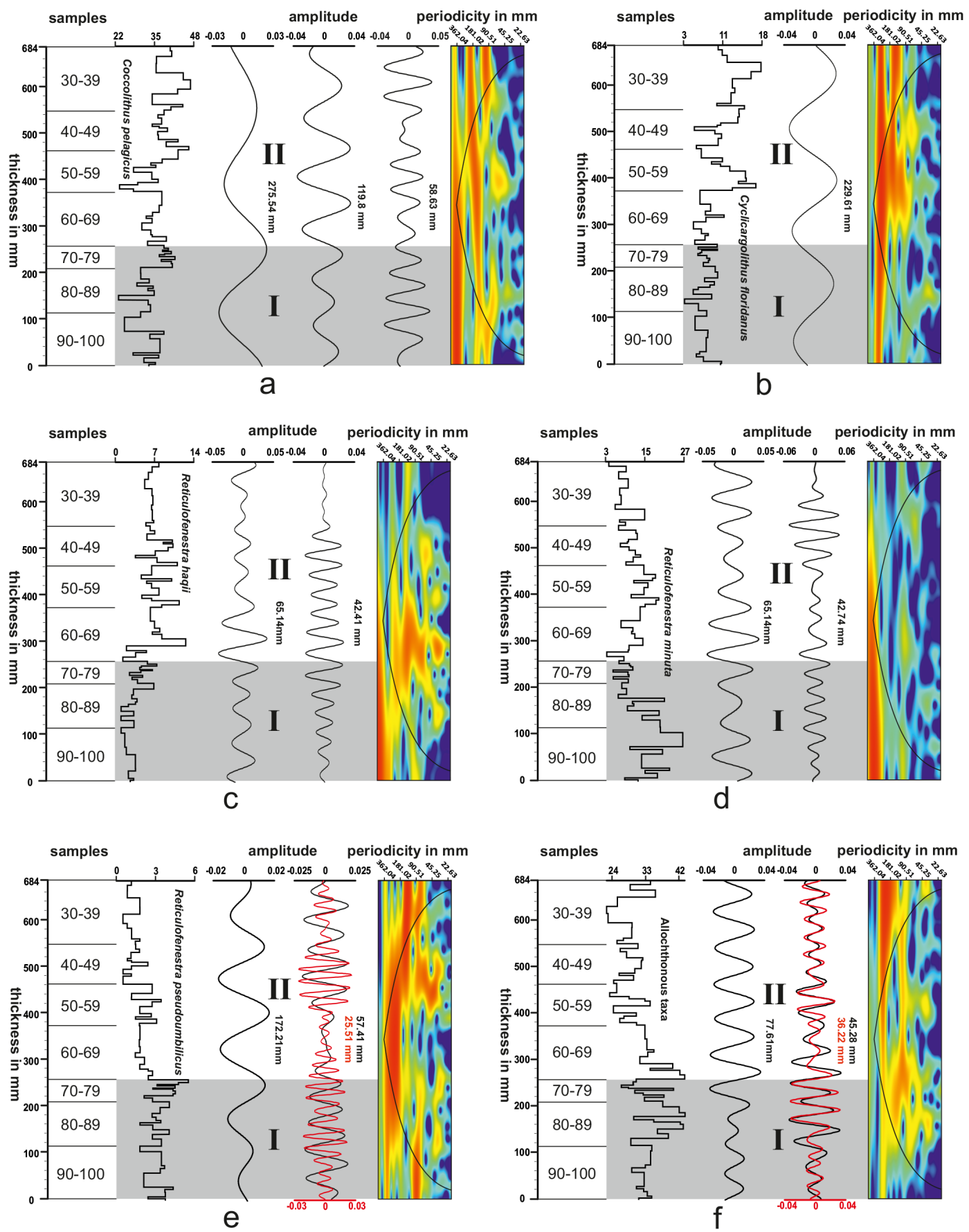

Figure 8. Paleobiological proxies (a: Coccolithus pelagicus; b: Cyclicargolithus floridanus; $\mathbf{c}:$ Reticulofenestra haqii; d: Reticulofenestra minuta; e: Reticulofenestra pseudoumbilicus; and f: allochthonous taxa): data were transformed to reflect thicknesses of the sampled layers and filtered according to the periodicities detected by REDFIT. Gaussian filters applied to the periodicities use a bandwidth of $25 \%$ of the filtered frequency. Wavelet spectra were used to evaluate the frequencies for spectral shifts; red areas of the wavelet indicate stronger amplitudes.

for long eccentricity to short eccentricity to obliquity to precession (400:100:41:20 kyr) cycles. Based on this, solar cycles show a relationship of $\sim 1: 1.8: 3.2: 9.5: 19$ for the Suess/de Vries to upper Gleissberg to lower Gleissberg to Hale to Schwabe $(208: 115: 65: 22: 11$ years) cycles. Use of the spectral relationship detected in the data set and comparing it with the unique $1: 1.8: 3.2$ relationship observed in the Suess/de Vries and both Gleissberg cycles shows that the detected periodicities closely match this pattern in our data set, while also matching the two larger unnamed cycles 
with a 400- and 500-year periodicity, respectively. The presence of this relationship, as well as the fact that solar cycles are the only known and likely stable cycles in the centennial to millennial band (Weedon, 2003; Kern et al., 2012, 2013), makes them the best suited tuning target for the detected periodicities.

While short-term variations in the sedimentation rate will naturally occur within a natural environment, time-averaged rates of sedimentation accumulation were likely constant for the investigated section. This assumption is supported by both REDFIT and wavelet analyses, since they show clear peaks, with only slight evidence of peak broadening, indicative of smaller-scale variations in sedimentation rate small enough not to mask the preserved cycles. This indicates that sedimentation rates remained relatively constant with only negligible variation for the studied section. Further support is given by the presence of similar cyclic patterns in two unrelated data sets. This relative stability of sedimentation rates can be explained by a process of time averaging caused by the sampling distance of $\sim 10 \mathrm{~mm}$. It can be thus assumed that, over the span of the deposition of one layer, which should roughly equal one to two decades, minor annual variations in the sedimentation budged are averaged to a more or less constant mean which remained constant for the section.

\subsection{Tuning of the age-depth model to solar cycles}

Since the observed cycles show a remarkably similar spectral relationship to known solar cycles, a best-fit adjustment can be used to tune the recorded cycles. Considering the sedimentary history and studies in similar settings, a sedimentation rate of $512 \mathrm{~mm} \mathrm{kyr}^{-1}$ was used as an initial starting point for the tuning. Using this approach allows the simple conversion of the periodicities in millimeters calculated by REDFIT and wavelet analyses into time-based cyclicities (Figs. 7, 8; Table 3), which allows for a more straightforward comparison to solar cycles. This also simplifies the subsequent tuning, since cycles are commonly presented in years and not in frequencies.

Organizing our results in this manner reveals that most detected cycles can be roughly arranged into groups of similar periodicities: the first group encompasses all periodicities below 65 years and thus contain three periodicities -60.47 (calcium carbonate), 64.84 (TOC), and 48.83 years (Reticulofenestra pseudoumbilicus). The second group ranges between 70 and 80 years and encompasses three periodicities: 75.8 (calcium carbonate), 70.81 (sulfur), and 70.74 years (allochthonous taxa). A third group is formed by periodicities ranging between 80 and 90 years, including four periodicities: 86.8 (sulfur), 82.83 (Reticulofenestra haqii), 83.48 (Reticulofenestra minuta), and 88.43 years (allochthonous taxa). A fourth group can be formed with four periodicities between 110 and 130 years. The group contains: 114.51 (Coccolithus pelagicus), 127.33 (Reticulofenestra haqii), 127.23 (Reticulofenestra minuta), and 112.12 years
(Reticulofenestra pseudoumbilicus). The two slightly more isolated periodicities of 151.58 (allochthonous taxa) and 179.38 years (calcium carbonate) were also grouped. Another group of three periodicities forms around an average of 237.53 years, and encompasses the periodicities 244.62 (sulfur), 233.98 (TOC), and 233.99 years (Coccolithus pelagicus). Two other periodicities appear at 298.98 (calcium carbonate) and 336.35 years (Reticulofenestra pseudoumbilicus) and form an average of 317.67 years. The last two remaining periodicities appear to be completely separated at 448.46 (Cyclicargolithus floridanus) and 538.16 years (Coccolithus pelagicus). Comparison of the detected periodicities with known cycles linked to solar variation, such as the Gleissberg (Wolf, 1892; Gleissberg, 1939; Ogurtsov et al., 2002) and Suess/de Vries cycles (Damon and Sonett, 1991; Stuiver and Braziunas, 1993; Wagner et al., 2001), shows a clear correlation. For instance, the Gleissberg cycle is split into two distinct frequency components, centered on 50-80 and 90-140 years (Ogurtsov et al., 2002). The Suess/de Vries cycle centers on a periodicity of 208 years and is well documented in Holocene (Schimmelmann et al., 2003; Yin et al., 2007; Raspopov et al., 2008; Taricco et al., 2009; Incarbona et al., 2010; Kern et al., 2012, 2013; Di Rita, 2013; Galloway et al., 2013) and Late Miocene (Pannonian) records (Kern et al., 2012, 2013). Comparing the average age ranges of the detected periodicity groups with the known ranges for the Gleissberg and Suess/de Vries cycle shows that nearly all values are slightly higher than the known periodicities of the established cycles. Since all cycles appear to be consistently higher, it can be assumed that the estimated sedimentation rate of $512 \mathrm{~mm} \mathrm{kyr}^{-1}$ is too low. Using a bestfit adjustment, the sedimentation rate was then adjusted to tune the detected cycles to known periodicities of solar variation (Solanki et al., 2004; Kern et al., 2012, 2013), using an iterative step-wise approach until the best possible fit was achieved. This method results in an adjusted sedimentation rate value of $575 \mathrm{~mm} \mathrm{kyr}^{-1}$. Corresponding rates of sediment accumulation have been reported from recent shallow marine areas such as the western Adriatic Sea (Frignani et al., 2005) and the Mediterranean continental margin (Sanchez-Cabeza et al., 1999). Similarly, the Santa Barbara Basin shows high rates of sediment accumulation (often reaching $1.4 \mathrm{~mm} \mathrm{yr}^{-1}$ ), anoxic conditions, and high primary productivity (Stein and Rack, 1992; Behl, 1995; Thunell et al., 1995), showing that the proposed sedimentation rates are reasonable considering the known paleoenvironmental conditions of the investigated outcrop (Auer et al., 2014).

Based on these assumptions the recalculated time values now fit very well within the reported ranges for the Upper and the Lower Gleissberg cycle, as well as the Suess/de Vries cycle, without further need for individual adjustment of cycles or sedimentation rates. Calculating the average of all values that lie within the reported ranges of the cycle gives mean values of 127.22 years for all periodicities associated with the Upper Gleissberg cycle and an average of 64.17 years for 
the Lower Gleissberg cycle. Similarly, the average of periodicities associated with the Suess/de Vries cycle now average 211.5 years (Table 3 ). This adjustment preserves the $1: 1.8: 3.2$ relationship observed for cycles of solar variation in the decadal to centennial band observed in the data (Kern et al., 2012).

Likewise, the 399.32-year periodicity fits well with a reported 400-year cycle that was detected in multiple studies of both marine and lacustrine sediments from the Holocene (Dean and Schwalb, 2000; Domack et al., 2001; Dean et al., 2002). The detected periodicity of 479.20 years $(275.54 \mathrm{~mm})$ may be loosely linked to an unnamed 500-year cycle (Stuiver et al., 1995; Chapman et al., 2000). Yin et al. (2007) and Kern et al. (2012) detected comparable periodicities related to this cycle in Holocene and Late Miocene records (Table 3).

The detection of cycles with higher frequencies, like the well-known $\sim 11$-year sunspot or Schwabe cycle (Schwabe, 1844 ), as well as the closely related $\sim 22$-year Hale cycle, was inhibited by the sample spacing, as one sample is roughly equivalent to a time of 15 years in our current model. Furthermore, the Nyquist frequency, which is the theoretical limit, states that a sinusoidal curve can only be expressed by at least two samples, making any cycle below $\sim 34$ years impossible to detect in our material (Weedon, 2003). Most cycles are far above the significance threshold of four samples per sinusoid ( $\sim 68$ years) recommended by Weedon (2003).

\subsection{Time estimates}

Based on the remarkably close fit of detected periodicities after tuning to the temporal ranges of all cycles of solar variation, age estimates can be calculated for the high-resolution section. Assuming our assumptions are correct, the tuning results in roughly 1190 years contained within the $684 \mathrm{~mm}$ of the high-resolution section of Laa an der Thaya. Assuming that time-averaged sedimentation rates did not vary significantly over the total time represented within the $5.5 \mathrm{~m}$ outcrop in the clay pit of Laa an der Thaya can be roughly estimated as no more than $\sim 10 \mathrm{kyr}$.

\subsection{Ecological interpretation}

Assuming that the best-fit tuning indeed reflects solar cycles, the individual periodicities of the nine different proxies can now be further evaluated with respect to how the different cycles influenced them. Significant frequencies are present in most proxies, the intensity of their response, however, differs from each other. This seems to indicate that different solar cycles are expressed in a unique way in each proxy. Kern et al. $(2012,2013)$ came to a similar conclusion based on their study of Late Miocene lake sediments. Further analysis of these frequencies and their relationship with regards to different proxies, however, requires at least basic information on the controlling ecological parameters. The precise factors controlling the abundance and distribution of differ- ent calcareous nannoplankton taxa, however, are still a matter of discussion, even in modern oceans (e.g., Ziveri et al., 2004). Nevertheless, some general statements can be made for key taxa that allow for interpretations concerning productivity, availability of nutrients, and surface water temperature when comparing them directly to other taxa (see Haq, 1980; Ziveri et al., 2004; Wade and Bown, 2006; Auer et al., 2014). This allows for comparison of recorded taxa in terms of relative changes to each other, focusing on their most often observed ecological preferences and describing observed cyclic patterns in the analyzed proxies. The following discussion is thus only based on the comparison of commonly referenced ecological preferences of coccolith taxa. This approach has already yielded promising results, revealing short-term small-scale changes in sea level (Auer et al., 2014).

For the purpose of this work, the ecological preferences of two taxa are of particular importance: Coccolithus pelagicus and Reticulofenestra. Coccolithus pelagicus is often described as a species indicative of heightened fertility, especially related to upwelling conditions. The assumption is based on the fact that $C$. pelagicus is commonly considered a cool-water taxon, which is also a good tracer of upwelling fronts, based on the ecological preferences of the two extant subspecies $C$. pelagicus ssp. pelagicus and C. pelagicus ssp. braarudii (Cachão and Moita, 2000; Ziveri et al., 2004; Wade and Bown, 2006; Silva et al., 2008; Auer et al., 2014). Considering the paleogeographical position of the section, this allows the use of cyclic variations in the abundance of $C$. pelagicus as a rough proxy for relative short-term changes in upwelling conditions and to a minor degree for temperature. This is, however, only applicable in a direct comparison to other taxa in the assemblage (see Auer et al., 2014).

For the genus Reticulofenestra, literature data suggest that all Early Miocene reticulofenestrids can be broadly associated with raised nutrient levels of terrestrial origin (Okada and Honjo, 1973; Haq, 1980; Aubry, 1992; Flores et al., 1995; Okada and Wells, 1997; Wade and Bown, 2006). $R$. minuta, the most common reticulofenestrid in the section, in particular is usually seen as an opportunistic taxon that is able to thrive in eutrophic conditions on continental margin settings (Aubry, 1992; Flores, 1995; Wade and Bown, 2006). We thus consider variation in the amount of reticulofenestrids indicative of heightened input of terrigenous nutrients caused by increased riverine input in a direct comparison with other dominant taxa in the assemblage (Auer et al., 2014).

The cross-examination of the periodicities in all studied proxy data using this approach has revealed striking similarities in the periodicities for proxies that can be linked to the same environmental parameters. This coupled response of different and unrelated proxies for the same environmental parameters strongly hints at a preservation of a cyclic climate variation within these proxies linked to solar variation. 
One such similarity is the strong evidence of the $119.8 \mathrm{~mm}$ periodicity in TOC and Coccolithus pelagicus, with a similar peak $(125.25 \mathrm{~mm})$ in sulfur. TOC is considered a good indicator of primary productivity in the oceans (Rohling, 1994; Vilinski and Domack, 1998; Kuypers et al., 2004; Meyers and Arnaboldi, 2005). The content of sulfur in the sediment is a good indicator of dysoxic to anoxic bottom water conditions, which usually occur when input of organic matter into the sediment is increased due to high primary productivity (Berner, 1981; Maynard, 1982; Berner and Raiswell, 1984). Within the studied section, periodic variations thus likely reflect subtle changes in both primary productivity and bottom water oxygenation that were influenced by various ecological parameters.

Comparison of these factors with a similar peak pattern in the REDFIT analysis points towards a cyclic variation influencing primary productivity, oxygen content, and the abundance of $C$. pelagicus. Consequently, their strong relationship offers a good indicator that the cyclic variation in TOC and sulfur is related to subtle changes in primary productivity and thus small variations in bottom water oxygenating and organic carbon burial. This observed relationship could be explained by a cyclic variably of locally confined upwelling and/or increased mixing of the water column, likely caused by changes in local wind patterns. A similar relationship between upwelling and cycles of solar variation has been found in previous studies for the Holocene (Santos et al., 2011). Assuming the best-fit tuning of the age model is correct, these cyclicities can thus be strongly linked to the $\sim 208$-year Suess/de Vries cycle observed in solar variation.

A weak link between the major periodicities detected for the calcium carbonate content and the amount of allochthonous taxa suggests that the calcium carbonate content in the section was also influenced by the terrigenous input into the sediment. Since coccolithophores produced more massive coccoliths during the Cretaceous (Stanley et al., 2005) compared to Early Miocene coccolith taxa, allochthonous taxa have a significant contribution to the calcium carbonate content. The similarities between the content of allochthonous taxa and calcium carbonate can thus be seen as an expression of changing terrigenous input caused by variations in precipitation. In addition, the same cyclicities also occur to a varying degree in the abundance of Reticulofenestra. As reticulofenestrids often thrive in terrigenous nutrient influenced eutrophic near shore environments, it seems reasonable that the occurrence of similar cyclic patterns in both proxies is linked to the same cause. The amount of terrigenous nutrients is principally influenced by the amount of precipitation in the hinterland. This is further supported by the reported wet and warm temperate to subtropical conditions in the Paratethys region with a continuous cover of subtropical to deciduous vegetation during the late Early Miocene (Böhme, 2003; Kern et al., 2011). A link between precipitation and riverine input seems thus a likely cause of the observed cyclic variations in allochthonous ma- terial (i.e., the composition of silt sized sediment) as well as the input of terrigenous nutrients. Comparable processes are recorded for riverine input for the Holocene records of the Mediterranean (Martinez-Ruiz et al., 2015). Consequently, using the best-fit age model, our analyses indicate that the Upper ( 90-140 years) and Lower ( 50-80 years) Gleissberg cycle likely forced changes in local precipitation.

The fluctuations in nutrient availability also become apparent in the sulfur content, since the amount of sulfur is directly linked to lowered oxygen conditions at the sea floor caused by increased primary productivity as a result of higher fertility levels through terrigenous influx (Berner, 1981; Maynard, 1982; Berner and Raiswell, 1984). This effect may have been further amplified by increased water stratification caused by significant freshwater input, which exerted a positive feedback on the oxygen content of bottom waters, resulting in slight periodic variations in oxygen content (e.g., Schulz et al., 2005).

The influence of the similar forcing that affected different ecological parameters also becomes apparent in a direct comparison of the filtered amplitudes in the studied proxies with the paleoenvironmental reconstruction based on geochemical analyses and calcareous nannoplankton assemblages of Auer et al. (2014). A shift in amplitude occurs in some parameters that corresponds well with the observed changes of paleoenvironmental conditions from a more near-shore freshwater influenced setting in the lower part compared to the more upwelling-dominated upper part of the studied section. This shift is clearly visible in the wavelet spectra of sulfur and TOC contents, as well as the relative abundances of Coccolithus pelagicus. Amplitudes of these proxies are generally lower in the lower part compared to the upper part, indicating that a setting closer to the shore is subject to a stronger overprint of solar variation in the ecological signal compared to a more distal setting.

Conversely, proxies with a strong connection to precipitation, freshwater influx, and terrigenous nutrient input, such as calcium carbonate content, Reticulofenestra haqii, $R$. min$u t a, R$. pseudoumbilicus, and the amount of allochthonous taxa, seem to be much less influenced by this shift in the depositional environment, indicating that the influence of terrigenous input remained constant throughout the section, while upwelling only occurred in the more distal setting, which influenced the upper part of the analyzed section (Auer et al., 2014).

A complex link between cosmic rays emitted by the sun and the amount of cloud cover has been previously discussed (e.g., Svensmark and Friis-Christensen, 1997; Kristjánsson et al., 2004; Erlykin et al., 2010). This proposed link, while quite tenuous (see Erlykin et al., 2010), gives some evidence that solar cycles influence global climate through a complex link between variations in the cloud cover that cause variations in the planet's albedo. Similarly, there is evidence that differences in the UV irradiation of the stratosphere have a strong impact on ozone production and thus heating of the 


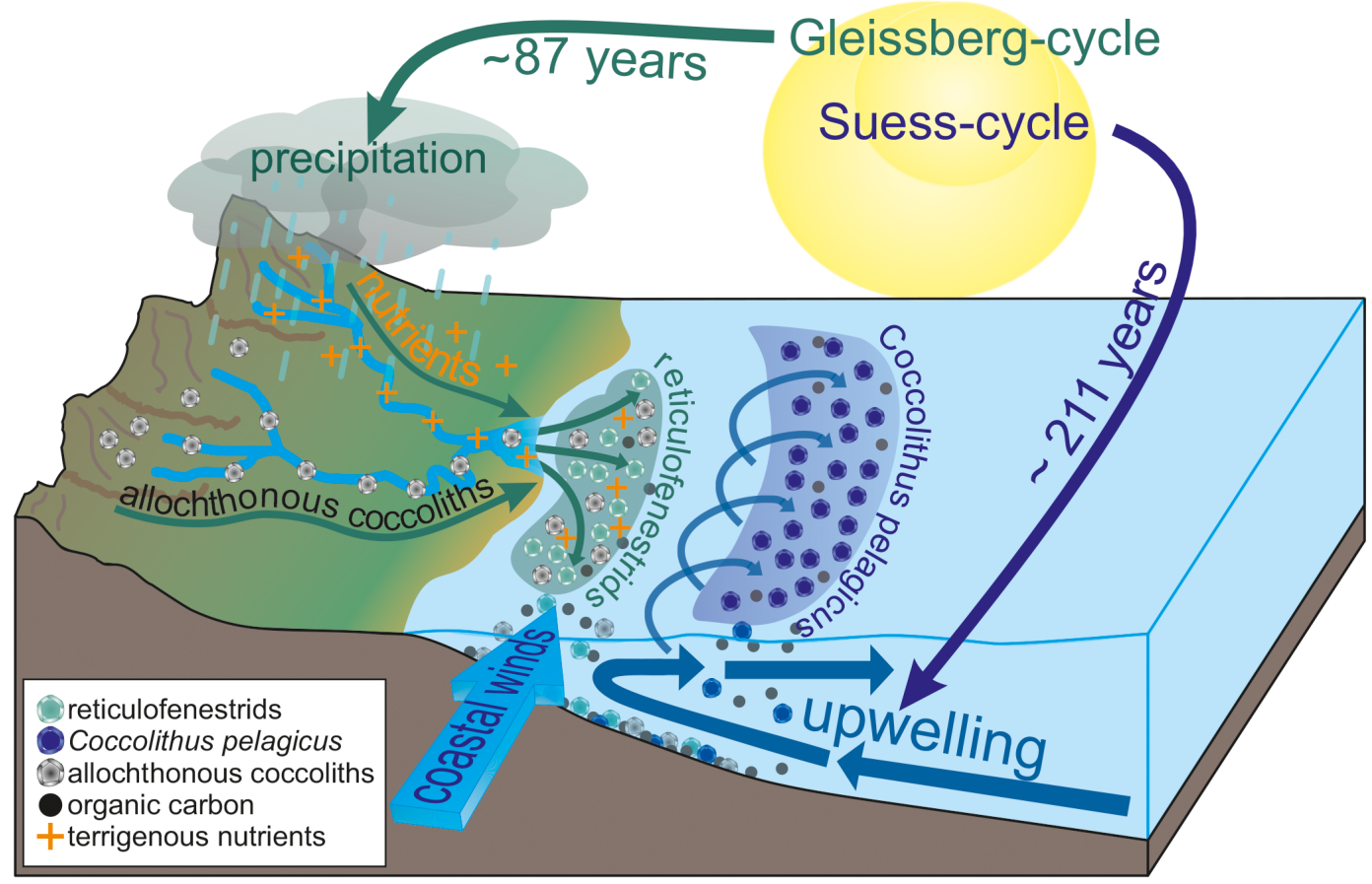

Figure 9. Model depicting the Suess and Gleissberg cycles and the dominant influence they had on different paleoenvironmental systems. The (combined upper $\sim 113$ years and lower $\sim 65$ years) Gleissberg cycle exerts control on precipitation, which in turn controls freshwater and terrigenous material input as well as nutrient influx from the hinterland, and variations in the abundance of reticulofenestrids. The Suess cycle ( $\sim 211$ years) in turn exerts control over local coastal upwelling, as well as the amount of Coccolithus pelagicus. Both cycles are reflected in primary productivity proxies, caused by the export of organic matter from both systems to the ocean floor.

troposphere. This effect on the troposphere, in turn, may have influenced storm-tract paths and mid- to low-latitude precipitation according to Kerr (1999) and Shindell et al. (1999). The strength of the North Atlantic Oscillation in particular seems to be heavily influenced by this process on a decadal to centennial scale (Shindell et al., 2001).

This may explain how precipitation as well as wind patterns is controlled by solar variation as both are likely an expression of variations in decadal to millennial temperature patterns. Temperature variations subsequently induced the inferred variability in precipitation and wind patterns. With this considered, our results suggest that precipitation was much more sensitive to the Gleissberg cycles, whereas larger-scale wind patterns controlling upwelling appear to be linked to the longer Suess/de Vries cycle. While our results provide initial evidence of this relationship, more detailed studies are, however, needed to verify and validate this interpretation. In particular, comparable studies need to be performed in different settings to exclude system intrinsic variations in the Central Paratethys as the cause of the observed periodicities and to further test the applied best-fit tuning in sections where an independent age control is available.

\section{Conclusions}

The cyclic nature of climatic changes preserved in a total of nine geochemical and paleoecological proxies was studied using time series analysis (REDFIT analysis and wavelet spectra). All proxies display highly similar periodicities, although some variations in power and their exact location within the frequency band occur. Our results expand on a previous study focused on changes in paleoenvironmental conditions caused by changes in relative sea level (Auer et al., 2014) and reveal a strong influence of small-scale, shortterm climate variability on local paleoenvironmental conditions caused by cyclic variations in solar activity.

With a best-fit adjustment of detected cycles to known cycles of solar origin, the detected periodicities correspond remarkably well with cycles of solar variation present in Holocene sun spot records and Late Miocene lake records. Assuming the applied tuning is accurate, the section appears to be influenced by the Lower ( $\sim 65$ years) and Upper ( $\sim 113$ years) Gleissberg cycle, as well as the 211-year Suess/de Vries cycle. Other reported solar cycles of $\sim 400$ and $\sim 500(\sim 480)$ years are also represented but less significant. Best-fit adjustment of sedimentation rates resulted in an estimated $575 \mathrm{~mm} \mathrm{kyr}^{-1}$ for the high-resolution section, resulting in a time span of $\sim 1190$ years for the $684 \mathrm{~mm}$ thick section. 
Accepting the hypothesis that these cycles represent environmental responses to known solar cycles, the integrated study of multiple paleoenvironmental proxies revealed a complex interplay of solar variation with the environment (Fig. 9). While variations in coccolith abundances and geochemical data show a clear correlation with the calculated solar cycles, their response to different cycles varies considerably. Similar responses to solar forcing were found within proxies related to the same ecological parameters, indicating that the observed cyclicities represent a clear influence of solar forcing on climatic conditions. Based on this, we found that the Upper and Lower Gleissberg cycles appear to be a driving factor for the amount of terrigenous influx into the ocean. This link is reflected in the amount of allochthonous taxa, a direct proxy for terrigenous input, and also the abundance of reticulofenestrids, a proxy for freshwater influx and availability of terrigenous nutrients. This suggests that precipitation rather than wind was the key factor (Fig. 9). Upwelling conditions and water temperature, in turn, were controlled by the longer Suess/de Vries cycle, reflected in a similar response of Coccolithus pelagicus, a typical tracer for upwelling fronts (and thus coastal wind systems), and cooler sea surface temperatures (Fig. 9). TOC and sulfur, both indicators of increased primary productivity, and anoxic bottom water conditions, often associated with high primary productivity, were conversely influenced by both cyclic systems, reflecting organic matter flux from both terrigenous nutrients and upwelling-driven primary productivity (Table 1; Figs. 6 , $7,9)$.

\section{The Supplement related to this article is available online at doi:10.5194/cp-11-283-2015-supplement.}

Acknowledgements. The authors would like to thank Stjepan Ćorić (Geological Survey of Austria, Vienna), Patrick Grunert (University of Graz), and Andrea Kern (State Museum of Natural History Stuttgart) for many helpful comments and discussions. We also would like to thank Marie-Pierre Aubry (Rutgers University) for providing key literature. Additional thanks go to the participants of the field course "Paleontological Lab- and Fieldwork" for their help with sampling and the logging of the outcrop, as well as David Strahlhofer (University of Graz) for his assistance with sample preparation in the lab. The authors would also like to thank the three anonymous reviewers for their many helpful suggestions and comments. Funding for this study was provided by the FWF (grant P-23492-B17)

Edited by: A. Sluijs

\section{References}

Adamek, J., Brzobohaty, R., Palensky, P., and Sikula, J.: The Karpatian in the Carpathian Foredeep (Moravia), in The Karpatian - A Lower Miocene Stage of the Central Paratethys, edited by R. Brzobohaty, I. Cicha, M. Kovác, and F. Rögl, Masaryk University, Brno, 75-89, 2003.

Amore, F. O., Flores, J. A., Voelker, A. H. L., Lebreiro, S. M., Palumbo, E., and Sierro, F. J.: A Middle Pleistocene Northeast Atlantic coccolithophore record: Paleoclimatology and paleoproductivity aspects, Mar. Micropaleontol., 90-91, 44-59, 2012.

Aubry, M.-P.: Handbook of Cenozoic Calcareous Nannoplankton: Book 1. Ortholithae (Discoasters), Micropaleontology Press, New York, 1984.

Aubry, M.-P.: Handbook of Cenozoic Calcareous Nannoplankton: Book 2. Ortholithae (Holococcoliths, Ceratoliths, Ortholiths and Others), Micropaleontology Press, New York, 1988.

Aubry, M.-P.: Handbook of Cenozoic Calcareous Nannoplankton: Book 3. Ortholithae (Pentaliths, and Others), Heliolithae (Fasciculiths, Sphenoliths and Others), Micropaleontology Press, New York, 1989.

Aubry, M.-P.: Handbook of Cenozoic Calcareous Nannoplankton: Book 4. Heliolithae (Helicoliths, Cribriliths, Lopadoliths and Others), Micropaleontology Press, New York, 1990.

Aubry, M.-P.: Late Paleogene calcareous nannoplankton evolution: a tale of climatic deterioration, in: Eocene-Oligocene Climatic and Biotic Evolution, edited by: Prothero, D. R. and Berggren, W. A., Princeton University Press, New Jersey, 272-208, 1992.

Aubry, M.-P.: Handbook of Cenozoic Calcareous Nannoplankton: Book 5: Heliolithae (Zygoliths and Rhabdoliths), Micropaleontology Press, New York, 1999.

Auer, G. and Piller W.E., Harzhauser M.: High-resolution calcareous nannoplankton palaeoecology as a proxy for small-scale environmental changes in the Early Miocene, Mar. Micropaleontol., 111, 53-65, 2014.

Álvarez, M. C., Flores, J. A., Sierro, F. J., Diz, P., Francés, G., Pelejero, C., and Grimalt, J. O.: Millennial surface water dynamics in the Ría de Vigo during the last 3000 years as revealed by coccoliths and molecular biomarkers, Palaeogeogr, Palaeoclimatol. Palaeoecol., 218, 1-13, 2005.

Backman, J., Raffi, I., Rio, D., Fornaciari, E., and Pälike, H.: Biozonation and biochronology of Miocene through Pleistocene calcareous nannofossils from low and middle latitudes, Newsl. Stratigr., 45, 221-244, 2012.

Behl, R. J.: Sedimentary facies and sedimentology of the late quaternary Santa Barbara Basin, Site 893, edited by: Kennett, J. P., Baldauf, J. G., and Lyle, M., Proc. ODP, Sci. Results, 146, 295308, 1995.

Berner, R. A.: A new geochemical classification of sedimentary environments, J. Sediment. Petrol., 51, 359-365, 1981.

Berner, R. A. and Raiswell, R.: C/S method for distinguishing freshwater from marine sedimentary rocks, Geology, 12, 365-368, 1984.

Böhme, M.: The Miocene Climatic Optimum: evidence from ectothermic vertebrates of Central Europe, Palaeogeogr. Palaeoclimatol. Palaeoecol., 195, 389-401, 2003.

Bown, P. R. and Young, J. R.: Techniques, in Calcareous Nannofossil Biostratigraphy, edited by: Bown, P. R., Chapman \& Hall, Cambridge, 16-28, 1998. 
Burnett, J. A.: Upper Cretaceous, in: Calcareous Nannofossil Biostratigraphy, edited by: Bown, P. R., Chapman \& Hall, Cambridge, 132-199, 1998.

Cachão, M. and Moita, M. T.: Coccolithus pelagicus, a productivity proxy related to moderate fronts off Western Iberia, Mar. Micropaleontol., 39, 131-155, 2000.

Chapman, M. R., Shackleton, N. J., and Chapman, M. R.: Evidence of 550-year and 1000-year cyclicities in North Atlantic circulation patterns during the Holocene, The Holocene, 10, 287-291, 2000.

Couapel, M. J. J., Beaufort, L., Jones, B. G., and Chivas, A. R.: Late Quaternary marginal marine palaeoenvironments of northern Australia as inferred from cluster analysis of coccolith assemblages, Mar. Micropaleontol., 65, 213-231, 2007.

Damon, P. E. and Sonett, C. P.: Solar and terrestrial components of the atmospheric C-14 variation spectrum, in: The Sun in Time, vol. 1, edited by: Sonett, C. P., Giampapa, M. S., and Matthews, M. S., Tuscon, AZ, University of Arizona Press, 360-388 1991.

Dean, W., Anderson, R., Platt Bradbury, J., and Anderson, D.: A 1500-year record of climatic and environmental change in Elk Lake, Minnesota I: Varve thickness and gray-scale density, J. Paleolimnol., 27, 287-299-299, 2002.

Dean, W. E. and Schwalb, A.: Holocene environmental and climatic change in the Northern Great Plains as recorded in the geochemistry of sediments in Pickerel Lake, South Dakota, Quatern. Int., 67, 5-20, 2000.

Dellmour, R. and Harzhauser, M.: The Iváň Canyon, a large Miocene canyon in the Alpine-Carpathian Foredeep, Mar. Petrol. Geol., 38, 83-94, 2012.

Di Rita, F.: A possible solar pacemaker for Holocene fluctuations of a salt-marsh in southern Italy, Quatern. Int., 288, 239-248, 2013.

Domack, E., Leventer, A., Dunbar, R., Taylor, F., Brachfeld, S., and Sjunneskog, C.: ODP Leg 178 Scientific Party: Chronology of the Palmer Deep site, Antarctic Peninsula: a Holocene palaeoenvironmental reference for the circum-Antarctic, The Holocene, 11, 1-9, 2001.

Erlykin, A. D., Sloan, T., and Wolfendale, A. W.: Correlations of clouds, cosmic rays and solar irradiation over the Earth, J. Atmos. Sol.-Terr. Phy., 72, 151-156, 2010.

Flores, J. A., Sierro, F. J., and Raffi, I.: Evolution of the calcareous nannofossil assemblage as a response to the paleoceanographic changes in the eastern equatorial Pacific Ocean from 4 to $2 \mathrm{Ma}$ (Leg 138, Sites 849 and 852), edited by: Pisias, N. G., Mayer, L. A., Janecek, T. R., Palmer-Julson, A. A., and van Andel, T. H., Proc. ODP, Sci. Results, College Sation, TX, 138, 163-176, 1995.

Fornaciari, E. and Rio, D.: Latest Oligocene to early middle Miocene quantitative calcareous nannofossil biostratigraphy in the Mediterranean region, Micropaleontology, 42, 1-36, 1996.

Fornaciari, E., Stefano, A. D., Rio, D., and Negri, A.: Middle Miocene Quantitative Calcareous Nannofossil Biostratigraphy in the Mediterranean Region, Micropaleontology, 42, 37-63, 1996.

Frignani, M., Langone, L., Ravaioli, M., Sorgente, D., Alvisi, F., and Albertazzi, S.: Fine-sediment mass balance in the western Adriatic continental shelf over a century time scale, Mar. Geol., 222-223, 113-133, 2005.

Galloway, J. M., Wigston, A., Patterson, R. T., Swindles, G. T., Reinhardt, E., and Roe, H. M.: Climate change and decadal to centennial-scale periodicities recorded in a late Holocene NE Pa- cific marine record: Examining the role of solar forcing, Palaeogeogr. Palaeoclimatol. Palaeoecol., 386, 669-689, 2013.

Galović, I. and Young, J. R.: Revised taxonomy and stratigraphy of Middle Miocene calcareous nannofossils of the Paratethys, Micropaleontology, 58, 305-334, 2012.

Girone, A., Maiorano, P., Marino, M., and Kucera, M.: Calcareous plankton response to orbital and millennial-scale climate changes across the Middle Pleistocene in the western Mediterranean, Palaeogeogr. Palaeoclimatol. Palaeoecol., 392, 105-116, 2013.

Gleissberg, W.: A long-periodic fluctuation of the sun-spot numbers, The Observatory, 62, 158-159, 1939.

Gradstein, F., Ogg, J., Schmitz, M., and Ogg, G., Eds.: The Geologic Time Scale 2012, Elsevier, Boston, 2012.

Gray, L. J., Beer, J., Geller, M., Haigh, J. D., Lockwood, M., Matthes, K., Cubasch, U., Fleitmann, D., Harrison, G., Hood, L., Luterbacher, J., Meehl, G. A., Shindell, D., van Geel, B., and White, W.: Solar Influences on Climate, Rev. Geophys., 48, RG4001, doi:10.1029/2009RG000282, 2010.

Gross, M., Piller, W. E., Scholger, R., and Gitter, F.: Biotic and abiotic response to palaeoenvironmental changes at Lake Pannons' western margin (Central Europe, Late Miocene), Palaeogeogr. Palaeoclimatol. Palaeoecol., 312, 181-193, 2011.

Grunert, P., Harzhauser, M., Rögl, F., Sachsenhofer, R. F., Gratzer, R., Soliman, A., and Piller, W. E.: Oceanographic conditions as a trigger for the formation of an Early Miocene (Aquitanian) Konservat-Lagerstätte in the Central Paratethys Sea, Palaeogeogr. Palaeoclimatol. Palaeoecol., 292, 425-442, 2010a.

Grunert, P., Soliman, A., Ćorić, S., Scholger, R., Harzhauser, M., and Piller, W. E.: Stratigraphic re-evaluation of the stratotype for the regional Ottnangian stage (Central Paratethys, middle Burdigalian), Newsl. Stratigr., 44, 1-16, 2010 b.

Grunert, P., Soliman, A., Harzhauser, M., Müllegger, S., Piller, W. E., Roetzel, R., and Rögl, F.: Upwelling conditions in the Early Miocene Central Paratethys Sea, Geologica Carpathica, 61, 129145, 2010c.

Grunert, P., Soliman, A., Ćorić, S., Roetzel, R., Harzhauser, M., and Piller, W. E.: Facies development along the tide-influenced shelf of the Burdigalian Seaway: An example from the Ottnangian stratotype (Early Miocene, middle Burdigalian), Mar. Micropaleontol., 84/85, 14-36, 2012.

Hammer, Ø.: Time series analysis with Past, Website of the Natural History Museum, University Oslo, 1-18, available at: http:// nhm2.uio.no/norlex/past/TimeseriesPast.pdf (last access: $12 \mathrm{Au}-$ gust 2012), 2010.

Hammer, Ø., Harper, D. A. T., and Ryan, P. D.: PAST: paleontological statistics software package for education and data analysis, Palaeontol. Electron., 4, 1-9, 2001.

Haq, B. U.: Biogeographic history of Miocene calcareous nannoplankton and paleoceanography of the Atlantic Ocean, Micropaleontology, 26, 414-443, 1980.

Harzhauser, M. and Piller, W. E.: Benchmark data of a changing sea - Palaeogeography, Palaeobiogeography and events in the Central Paratethys during the Miocene, Palaeogeogr. Palaeoclimatol. Palaeoecol., 253, 8-31, 2007.

Harzhauser, M., Mandic, O., Kern, A. K., Piller, W. E., Neubauer, T. A., Albrecht, C., and Wilke, T.: Explosive demographic expansion by dreissenid bivalves as a possible result of astronomi- 
cal forcing, Biogeosciences, 10, 8423-8431, doi:10.5194/bg-108423-2013, 2013.

Hohenegger, J. and Wagreich, M.: Time calibration of sedimentary sections based on insolation cycles using combined cross-correlation: dating the gone Badenian stratotype (Middle Miocene, Paratethys, Vienna Basin, Austria) as an example, Int. J. Earth. Sci. (Geol. Rundsch.), 101, 339-349, 2011.

Hohenegger, J., Ćorić, S., Khatun, M., Pervesler, P., Rögl, F., Rupp, C., Selge, A., Uchman, A., and Wagreich, M.: Cyclostratigraphic dating in the Lower Badenian (Middle Miocene) of the Vienna Basin (Austria): the Baden-Sooss core, Int. J. Earth. Sci. (Geol. Rundsch.), 98, 915-930, 2009.

Incarbona, A., Ziveri, P., Di Stefano, E., Lirer, F., Mortyn, G., Patti, B., Pelosi, N., Sprovieri, M., Tranchida, G., Vallefuoco, M., Albertazzi, S., Bellucci, L. G., Bonanno, A., Bonomo, S., Censi, P., Ferraro, L., Giuliani, S., Mazzola, S., and Sprovieri, R.: The impact of the Little Ice Age on coccolithophores in the Central Mediterranean Sea, Clim. Past, 6, 795-805, doi:10.5194/cp-6795-2010, 2010.

Kern, A. K., Harzhauser, M., Mandic, O., Roetzel, R., Ćorić, S., Bruch, A. A., and Zuschin, M.: Millennial-scale vegetation dynamics in an estuary at the onset of the Miocene Climate Optimum, Palaeogeogr. Palaeoclimatol. Palaeoecol., 304, 247-261, 2011.

Kern, A. K., Harzhauser, M., Piller, W. E., Mandic, O., and Soliman, A.: Strong evidence for the influence of solar cycles on a Late Miocene lake system revealed by biotic and abiotic proxies, Palaeogeogr. Palaeoclimatol. Palaeoecol., 329/330, 124-136, 2012.

Kern, A. K., Harzhauser, M., Soliman, A., Piller, W. E., and Mandic, O.: High-resolution analysis of upper Miocene lake deposits: Evidence for the influence of Gleissberg-band solar forcing, Palaeogeogr. Palaeoclimatol. Palaeoecol., 370, 167-183, 2013.

Kerr, R. A.: Link Between Sunspots, Stratosphere Buoyed, Science, 284, 234-235, 1999.

Kristjánsson, J. E., Kristiansen, J., and Kaas, E.: Solar activity, cosmic rays, clouds and climate - an update, Adv. Space Res., 34, 407-415, 2004.

Kuypers, M. M. M., Lourens, L. J., Rijpstra, W. I. C., Pancost, R. D., Nijenhuis, I. A., and Sinninghe Damsté, J. S.: Orbital forcing of organic carbon burial in the proto-North Atlantic during oceanic anoxic event 2, Earth Planet. Sci. Lett., 228, 465-482, 2004.

Lenz, O. K., Wilde, V., Riegel, W., and Harms, F.-J.: A 600 ky record of El Niño-Southern Oscillation (ENSO): Evidence for persisting teleconnections during the Middle Eocene greenhouse climate of Central Europe, Geology, 38, 627-630, 2010.

Le Treut, H., Somerville, R., Cubasch, U., Ding, Y., Mauritzen, C., Mokssit, A., Peterson, T., and Prather, M.: Historical Overview of Climate Change Science, in: Climate Change 2007: The Physical Science Basis, Contribution of Working Group I to the Fourth Assessment Report of the Intergovernmental Panel on Climate Change, vol. 1, edited by: Solomon, S., Qin, D., Manning, M., Chen, Z., Marquis, M., Averyt, K., Tignor, M. M. B., and Miller, H. L., Cambridge University Press, United Kingdom and New York, NY, USA, 94-127, 2007.

Lindqvist, J. K. and Lee, D. E.: High-frequency paleoclimate signals from Foulden Maar, Waipiata Volcanic Field, southern New Zealand: An Early Miocene varved lacustrine diatomite deposit, Sediment. Geol., 222, 98-110, 2009.
Martinez-Ruiz, F., Kastner, M., Gallego-Torres, D., RodrigoGámiz, M., Nieto-Moreno, V., and Ortega-Huertas, M.: Paleoclimate and paleoceanography over the past 20000 years in the Mediterranean Sea Basins as indicated by sediment elemental proxies, Quat. Sci. Rev., 107, 25-46, 2015.

Martini, E.: Standard Tertiary and Quaternary calcareous nannoplankton zonation, in Proceedings of the Second Planktonic Conference Roma 1970, vol. 2, edited by: Farinacci, A., Edizioni Tecnoscienza, Rome, 739-785, 1971.

Maynard, J. B.: Extension of Berner's "New geochemical classification of sedimentary environments" to ancient sediments, J. Sediment. Petrol., 52, 1325-1331, 1982.

Mertens, K. N. J. M., Lynn, M., Aycard, M., Lin, H.-L., and Louwye, S.: Coccolithophores as palaeoecological indicators for shifts of the ITCZ in the Cariaco Basin during the late Quaternary, J. Quaternary Sci., 24, 159-174, 2009.

Meyers, P. A. and Arnaboldi, M.: Trans-Mediterranean comparison of geochemical paleoproductivity proxies in a mid-Pleistocene interrupted sapropel, Palaeogeogr. Palaeoclimatol. Palaeoecol., 222, 313-328, 2005.

Negri, A. and Giunta, S.: Calcareous nannofossil paleoecology in the sapropel S1 of the eastern Ionian sea: paleoceanographic implications, Palaeogeogr. Palaeoclimatol. Palaeoecol., 169, 101$112,2001$.

Nehyba, S. and Petrová, P.: Karpatian sandy deposits in the southern part of the Carpathian Foredeep in Moravia, Bull. Czech Geol. Surv., 75, 53-66, 2000.

Ogurtsov, M. G., Nagovitsyn, Y. A., Kocharov, G. E., and Jungner, H.: Long-Period Cycles of the Sun's Activity Recorded in Direct Solar Data and Proxies, Sol. Phys., 211, 371-394, 2002.

Okada, H. and Honjo, S.: The distribution of oceanic coccolithophorids in the Pacific, Deep-Sea Res., 20, 355-374, 1973.

Okada, H. and Wells, P.: Late Quaternary nannofossil indicators of climate change in two deep-sea cores associated with the Leeuwin Current off Western Australia, Palaeogeogr. Palaeoclimatol. Palaeoecol., 131, 413-432, 1997.

Paillard, D., Labeyrie, L., and Yiou, P.: Macintosh Program performs time-series analysis, Eos Trans. AGU, 77, 379-379, 1996.

Patterson, R. T., Prokoph, A., and Chang, A.: Late Holocene sedimentary response to solar and cosmic ray activity influenced climate variability in the NE Pacific, Sediment. Geol., 172, 67-84, 2004.

Patterson, R. T., Chang, A. S., Prokoph, A., Roe, H. M., and Swindles, G. T.: Influence of the Pacific Decadal Oscillation, El NiñoSouthern Oscillation and solar forcing on climate and primary productivity changes in the northeast Pacific, Quatern. Int., 310, 1-16, 2013.

Perch-Nielsen, K.: Cenozoic Calcareous Nanofossils, in Plankton Stratigraphy Volume 1, vol. 1, edited by: Bolli, H. M., Saunders, J. B., and Perch-Nielsen, K., Cambridge University Press, Cambridge, 427-554, 1985a.

Perch-Nielsen, K.: Mesozoic Calcareous Nannofossils, in Plankton Stratigraphy Volume 1, vol. 1. Planktic foraminifera, calcareous nannofossils and calpionellids, edited by: Bolli, H. M., Saunders, J. B., and Perch-Nielsen, K., Cambridge University Press, Cambridge., 329-426, 1985b.

Piller, W. E., Harzhauser, M., and Mandic, O.: Miocene Central Paratethys stratigraphy-current status and future directions, Stratigraphy, 4, 71-88, 2007. 
Raspopov, O. M., Dergachev, V. A., Esper, J., Kozyreva, O. V., Frank, D., Ogurtsov, M. G., Kolström, T., and Shao, X.: The influence of the de Vries ( $\sim 200$-year) solar cycle on climate variations: Results from the Central Asian Mountains and their global link, Palaeogeogr. Palaeoclimatol. Palaeoecol., 259, 6-16, 2008.

Roetzel, R. and Schnabel, W.: Molasse, Waschbergzone, Paläogen und Neogen auf der Böhmischen Masse, in: Legende und Kurzerläuterung der Geologischen Karte von Niederösterreich, $1: 200.000$, edited by: W. Schnabel, Geologische Bundesanstalt, Vienna, 23-30, 2002.

Roetzel, R., Ćorić, S., Galović, I., and Rögl, F.: Early Miocene (Ottnangian) coastal upwelling conditions along the southeastern scarp of the Bohemian Massif (Parisdorf, Lower Austria, Central Paratethys), Beitr. Paläont., 30, 387-413, 2007.

Rohling, E. J.: Review and new aspects concerning the formation of eastern Mediterranean sapropels, Mar. Geol., 122, 1-28, 1994.

Sanchez-Cabeza, J. A., Masqué, P., Ani-Ragolta, I., Merino, J., Frignani, M., Alvisi, F., Palanques, A., and Puig, P.: Sediment accumulation rates in the southern Barcelona continental margin (NW Mediterranean Sea) derived from $210 \mathrm{~Pb}$ and $137 \mathrm{Cs}$ chronology, Prog. Oceanogr., 44, 313-332, 1999.

Santos, F., Gómez-Gesteira, M., deCastro, M., and Álvarez, I.: Upwelling along the western coast of the Iberian Peninsula: dependence of trends on fitting strategy, Clim. Res., 48, 213-218, 2011.

Schimmelmann, A., Lange, C. B., and Meggers, B. J.: Palaeoclimatic and archaeological evidence for a $\sim 200$-yr recurrence of floods and droughts linking California, Mesoamerica and South America over the past 2000 years, The Holocene, 13, 763-778, 2003.

Schulz, H. M., Bechtel, A., and Sachsenhofer, R. F.: The birth of the Paratethys during the Early Oligocene: From Tethys to an ancient Black Sea analogue?, Global Planet. Change, 49, 163-176, 2005.

Schulz, M. and Mudelsee, M.: REDFIT: estimating red-noise spectra directly from unevenly spaced paleoclimatic time series, Comput. Geosci., 28, 421-426, 2002.

Schwabe, H.: Sonnen - Beobachtungen im Jahre 1843, Astronomische Nachrichten, 21, 234-235, 1844.

Shindell, D., Rind, D., Balachandran, N., Lean, J., and Lonergan, P.: Solar Cycle Variability, Ozone, and Climate, Science, 284, 305-308, 1999.

Shindell, D. T., Schmidt, G. A., Mann, M. E., Rind, D., and Waple, A.: Solar Forcing of Regional Climate Change During the Maunder Minimum, Science, 294, 2149-2152, 2001.

Silva, A., Palma, S., and Moita, M. T.: Coccolithophores in the upwelling waters of Portugal: Four years of weekly distribution in Lisbon bay, Cont. Shelf Res., 28, 2601-2613, 2008.

Sokal, R. R. and Rohlf, F. J.: Biometry, 3rd ed., W. H. Freeman and Company, New York, 1995.

Solanki, S. K., Usoskin, I. G., Kromer, B., Schüssler, M., and Beer, J.: Unusual activity of the Sun during recent decades compared to the previous 11000 years, Nature, 431, 1084-1087, 2004.

Spezzaferri, S. and Ćorić, S.: Ecology of Karpatian (Early Miocene) foraminifers and calcareous nannoplankton from Laa an der Thaya, Lower Austria: A statistical approach, Geol. Carpathica, 52, 361-374, 2001.

Spezzaferri, S., Ćorić, S., Hohenegger, J., and Rögl, F.: Basin-scale paleobiogeography and paleoecology: an example from Karpatian (Latest Burdigalian) benthic and planktonic foraminifera and calcareous nannofossils from the Central Paratethys, Geobios, 35, 241-256, 2002.

Stanley, S. M., Ries, J. B., and Hardie, L. A.: Seawater chemistry, coccolithophore population growth, and the origin of Cretaceous chalk, Geology, 33, 593-596, 2005.

Stax, R. and Stein, R.: Data Report: Organic Carbon and Carbonate Records from Detroit Seamount and Patton-Murray Seamount: Results from Sites 882 and 887 (North Pacific Transect), edited by: Rea, D. K., Basov, L. A., Scholl, D. W., and Allan, J. F., Proc. ODP, Sci. Results, College Station, TX, 145, 645-655, 1995.

Stein, R. and Rack, F. R.: A 160000 -year high-resolution record of quantity and composition of organic carbon in the Santa Barbara Basin (Site 893), edited by: Kennett, J. P., Baldauf, J. G., and Lyle, M., Proc. ODP, Sci. Results, College Station, TX, 146, 125-138, 1992.

Stuiver, M. and Braziunas, T. F.: Sun, ocean, climate and atmospheric ${ }^{14} \mathrm{CO}_{2}$ : an evaluation of causal and spectral relationships, The Holocene, 3, 289-305, 1993.

Stuiver, M., Grootes, P. M., and Braziunas, T. F.: The GISP2 $\delta 180$ climate record of the past 16500 years and the role of the sun, ocean, and volcanoes, Quaternary Res., 44, 341-354, 1995.

Svabenicka, L., Ćorić, S., Andreyeva-Grigorovich, A. S., Halasova, E., Marunteanu, M., Nagymarosy, A., and OszczypkoClowes, M.: Central Paratethys Karpatian Calcareous Nannofossils, in: The Karpatian - A Lower Miocene Stage of the Central Paratethys, edited by: Brzobohaty, R., Cicha, I., Kovác, M., and Rögl, F., Masaryk University, Brno, 151-167, 2003.

Svensmark, H. and Friis-Christensen, E.: Variation of cosmic ray flux and global cloud coverage - a missing link in solar-climate relationships, J. Atmos. Sol.-Terr. Phy., 59, 1225-1232, 1997.

Taricco, C., Ghil, M., Alessio, S., and Vivaldo, G.: Two millennia of climate variability in the Central Mediterranean, Clim. Past, 5, 171-181, doi:10.5194/cp-5-171-2009, 2009.

Thunell, R. C., Tappa, E., and Anderson, D. M.: Sediment fluxes and varve formation in Santa Barbara Basin, offshore California, Geology, 23, 1083-1086, 1995.

Torrence, C. and Compo, G. P.: A Practical Guide to Wavelet Analysis, Bull. Amer. Meteor. Soc., 79, 61-78, 1998.

Varol, O.: Palaeogene, in: Calcareous Nannofossil Biostratigraphy, edited by: Bown, P. R., Chapman \& Hall, Cambridge, 200-224, 1998.

Villinski, J. C. and Domack, E.: Temporal changes in sedimentary organic carbon $\delta 13 \mathrm{C}$ from the Ross Sea, Antarctica: Inferred changes in ecosystems and climate, American Geophysical Union, Abstracts of Ocean Science Meeting, 1998.

Vos, H., Sanchez, A., Zolitschka, B., Brauer, A., and Negendank, J. F. W.: Solar Activity Variations Recorded in Varved Sediments From the Crater Lake, of Holzmaar - a Maar Lake in the Westeifel Volcanic Field, Germany, Surv. Geophys., 18, 163-182, 1997.

Wade, B. S. and Bown, P. R.: Calcareous nannofossils in extreme environments: The Messinian Salinity Crisis, Polemi Basin, Cyprus, Palaeogeogr. Palaeoclimatol. Palaeoecol., 233, 271-286, 2006.

Wagner, G., Beer, J., Masarik, J., Muscheler, R., Kubik, P. W., Mende, W., Laj, C., Raisbeck, G. M., and Yiou, F.: Presence of the Solar de Vries Cycle $(\sim 205$ years) during the Last Ice Age, Geophys. Res. Lett., 28, 303-306, 2001. 
Weedon, G. P.: Time-Series Analysis and Cyclostratigraphy: Examining Stratigraphic Records of Environmental Cycles, Cambridge University Press, 2003.

Wolf, R.: Astronomische Mittheilungen LXXIX, Astronomische Mitteilungen der Eidgenössischen Sternwarte Zurich, 8, 317364, 1892

Yin, Z. Q., Ma, L. H., Han, Y. B., and Han, Y. G.: Long-term variations of solar activity, Chinese Sci. Bull., 52, 2737-2741, 2007.
Young, J. R.: Neogene, in: Calcareous Nannofossil Biostratigraphy, edited by: Bown, P. R., Chapman \& Hall, Cambridge, 225-265, 1998.

Young, J. R., Bown, P. R., and Lees, J. A. (Eds.): Nannotax website, International Nannoplankton Association, available at: http: //nannotax.org, last access: 14 March 2013.

Ziveri, P., Baumann, K.-H., Böckel, B., Bollmann, J., and Young, J. R.: Biogeography of selected Holocene coccoliths in the Atlantic Ocean, in: Coccolithophores: From Molecular Processes to Global Impact, edited by: Thierstein, H. R. and Young, J. R., Springer, Berlin, Heidelberg, 403-428, 2004. 